\title{
Water limitations on forest carbon cycling and conifer traits along a steep climatic gradient in the Cascade Mountains, Oregon
}

\author{
L. T. Berner and B. E. Law \\ Department of Forest Ecosystems and Society, Oregon State University, Corvallis, Oregon \\ Correspondence to: L. T. Berner (logan.berner@oregonstate.edu)
}

Received: 6 August 2015 - Published in Biogeosciences Discuss.: 3 September 2015

Accepted: 1 November 2015 - Published: 19 November 2015

\begin{abstract}
Severe droughts occurred in the western United States during recent decades, and continued human greenhouse gas emissions are expected to exacerbate warming and drying in this region. We investigated the role of water availability in shaping forest carbon cycling and morphological traits in the eastern Cascade Mountains, Oregon, focusing on the transition from low-elevation, dry western juniper (Juniperus occidentalis) woodlands to higher-elevation, wetter ponderosa pine (Pinus ponderosa) and grand fir (Abies grandis) forests. We examined 12 sites in mature forests that spanned a $1300 \mathrm{~mm} \mathrm{yr}^{-1}$ gradient in mean growing-year climate moisture index $\left(\mathrm{CMI}_{\overline{\mathrm{gy}}}\right)$, computed annually (1964 to 2013) as monthly precipitation minus reference evapotranspiration and summed October to September. Maximum leaf area, annual aboveground productivity, and aboveground live tree biomass increased with $\mathrm{CMI}_{\overline{\mathrm{gy}}}\left(r^{2}=0.67-0.88\right.$, $P<0.05$ ), approximately 50-, 30-, and 10-fold along this drier to wetter gradient. Interannual fluctuations in CMI affected the annual radial growth of $91 \%$ of juniper, $51 \%$ of pine, and $12 \%$ of fir individuals from 1964 to 2013. The magnitude of the site-average growth-CMI correlations decreased with increased $\mathrm{CMI}_{\overline{g y}}\left(r^{2}=0.53, P<0.05\right)$. All three species, particularly fir, experienced pronounced declines in radial growth from c. 1985 to 1994, coinciding with a period of sustained below-average $\mathrm{CMI}_{\overline{g y}}$ and extensive insect outbreak. Traits of stress-tolerant juniper included short stature, high wood density for cavitation resistance, and high investment in water transport relative to leaf area. Species occupying wetter areas invested more resources in height growth in response to competition for light relative to investment in hydraulic architecture. Consequently, maximum tree height, leaf area : sapwood area ratio, and stem wood density were all correlated with $\mathrm{CMI}_{\overline{g y}}$. The tight coupling of for-
\end{abstract}

est carbon cycling and species traits with water availability suggests that warmer and drier conditions projected for the 21 st century could have significant biogeochemical, ecological, and social consequences in the Pacific Northwest.

\section{Introduction}

Droughts in the western United States had severe impacts on human and natural systems during the past century (Allen et al., 2010; Schwalm et al., 2012; Williams et al., 2012; Woodhouse and Overpeck, 1998), and sustained climatic warming due to human greenhouse gas emissions will likely exacerbate drought impacts over the coming century (Collins et al., 2013; Dai, 2013; Williams et al., 2012). Mean annual air temperatures in the western United States increased by 0.8-1. $1^{\circ} \mathrm{C}$ from 1895 to 2011 (Kunkel et al., 2013; Mote et al., 2014) and could rise an additional $5.4{ }^{\circ} \mathrm{C}$ by the end of the 21 st century (Walsh et al., 2014). Rising temperatures resulted in substantial reductions (up to $80 \%$ ) in spring snowpack across most mountain ranges in the region since observations became widespread in the 1950s (Mote et al., 2005, 2014), and during April 2015 snowpack was less than $25 \%$ of the 30-year average across the Cascade and Sierra Mountain ranges (USDA Natural Resources Conservation Service, 2015).

Tree-ring-based reconstructions indicate that very persistent, severe, and extensive droughts ("mega droughts") occurred over the past 1200 years in the western United States, especially during an abnormally warm period from around AD 900 to 1300 (Cook et al., 2004; Woodhouse et al., 2010), and suggest an increase in the area annually affected by drought over the 20th century (Cook et al., 2004). The most 
severe drought over the past 800 years occurred in 2000 2004 (Schwalm et al., 2012), and continued regional warming over the 21 st century is expected to produce droughts that are much more severe and persistent than the documented historical mega droughts (Collins et al., 2013; Dai, 2013; Schwalm et al., 2012; Williams et al., 2012), with widespread ecological and socioeconomic consequences (Diffenbaugh and Field, 2013; Jiang et al., 2013; Mote et al., 2014).

Water availability varies widely across the western United States and shapes the distribution and composition of forests, as well as forest carbon cycling. Mean annual precipitation (1971-2000) ranged from $<100 \mathrm{~mm} \mathrm{yr}^{-1}$ in parts of the southwest to $>5000 \mathrm{~mm} \mathrm{yr}^{-1}$ in parts of the Pacific Northwest, with spatial patterns largely governed by proximity to the ocean and the distribution of mountain ranges (Daly et al., 2008). Strong spatial gradients in water availability across this region play an important role in shaping the distribution of tree species and plant communities (Franklin and Dyrness, 1988; Mathys et al., 2014). For instance, droughttolerant western juniper (Juniperus occidentalis) form open woodlands in the dry foothills of the eastern Cascade Mountains, Oregon, while increased rainfall at higher elevations leads to a sequence of forest zones dominated by species with progressively lower drought tolerance, such as ponderosa pine (Pinus ponderosa), grand fir (Abies grandis Dougl.) and western hemlock (Tsuga heterophylla; Franklin and Dyrness 1988), and progressively higher leaf area, productivity and biomass (Gholz, 1982; Grier and Running, 1977). Warminginduced drought stress contributed to increased tree mortality rates (Allen, 2009; Peng et al., 2011; van Mantgem et al., 2009) and wildfire activity (Dennison et al., 2014; Westerling et al., 2006) in parts of western North America over the 20th century, and the rapid velocity of climate change projected for the 21st century (Loarie et al., 2009) is expected to drive pronounced, though relatively uncertain changes in forest distribution (Coops and Waring, 2011; Jiang et al., 2013; Rehfeldt et al., 2006) and biogeochemical cycling (Hudiburg et al., 2011; Jiang et al., 2013; Kang et al., 2014), with impacts dependent in part on species' morphological and physiological adaptations to drought stress (Law, 2014; McDowell and Allen, 2015).

Plants have evolved numerous adaptations to prevent hydraulic dysfunction but adaptations that allow plants to withstand very arid conditions often reduce their ability to compete in wetter, more productive environments. Water is used for myriad physiological processes (e.g., photosynthesis, heat dissipation, osmotic regulation; Kozlowski et al., 1991) and ascends from the soil into vascular plant canopies through xylem conduits, driven by tension imparted on the water column from molecules being evaporated from leaf substomatal chambers (Sperry, 2011; Tyree, 1997). Plants have adaptations to maintain xylem water potentials $(\Psi)$ within physiologically operable ranges so as to prevent runaway cavitation of the water column and subsequent hydraulic and photosynthetic impairment (Pockman et al., 1995; Sperry and Tyree, 1988) caused by low soil $\Psi$ and high atmospheric vapor pressure deficit (VPD; Whitehead et al., 1984). The xylem $\Psi$ required for substantial hydraulic impairment (e.g., $50 \%$ loss of hydraulic conductance (P50)) varies both within (Domec et al., 2009) and among species (Anderegg, 2015; Choat et al., 2012; Willson et al., 2008), depending in part on the mechanical strength of the xylem conduits, which tends to increase with wood density (Chave et al., 2009; Hacke et al., 2001; Jacobsen et al., 2007). When conditions are dry, some plants reduce stomatal conductance to help maintain xylem $\Psi$ within an operable range, yet this simultaneously reduces carbon assimilation and can lead to carbon starvation and mortality if sustained (McDowell, 2011). Plants can also manage xylem $\Psi$ by shedding leaves or, more gradually, by increasing investment in sapwood (Maherali and DeLucia, 2001; Mencuccini and Grace, 1995), either of which lowers the leaf: sapwood area ratio (LA:SA). Holding other factors constant, taller trees experience lower (i.e., more negative) xylem $\Psi$ at the top of the canopy due to increased gravitational pull and cumulative path-length resistance (Koch et al., 2004; Whitehead et al., 1984), which is potentially a key factor limiting maximum tree height in a given environment (Koch et al., 2004; Ryan and Yoder, 1997) and can predispose taller trees to drought-induced mortality (McDowell and Allen, 2015). Adaptations that enable plants to endure harsh abiotic stress (e.g., drought) often come at a competitive cost in more productive environments due to lower rates of resource acquisition and processing (Grime, 1974, 2001; Reich, 2014).

Given the potential socioeconomic and ecologic impacts it is imperative that we better understand how forest ecosystems in the western United States respond to spatial and temporal variations in water availability. Our objective in this study was to investigate how forest carbon cycling and conifer morphological traits responded to variation in water availability across a network of field sites in the eastern Cascade Mountains, Oregon, which included forests dominated by western juniper, ponderosa pine, and grand fir. We used the average growing-year climate moisture index $\left(\mathrm{CMI}_{\mathrm{gy}}\right.$; 1964-2013) as an indicator of water availability (Berner et al., 2013; Hogg and Hurdle, 1995), calculated as the difference between monthly precipitation (PPT) and reference evapotranspiration $\left(\mathrm{ET}_{0}\right)$ from October of year $t-1$ through September of year $t$ (see Supplement Table S1 for a key of abbreviations). The Cascade Mountains exhibit one of the steepest $\mathrm{CMI}_{\overline{g y}}$ gradients in North America (Fig. 1a), making it an excellent natural laboratory for studying plant adaptation and ecosystem response to water stress (e.g., Gholz, 1982; Law and Waring, 1994). We used a combination of stand survey, tree-ring, and morphological measurements to test the following three hypotheses.

Long-term water availability limits forest carbon cycling at low to mid-elevations in the eastern Cascade Mountains. Building on prior analyses in the region (Gholz, 1982; Grier and Running, 1977; Law and Waring, 1994), we predicted 

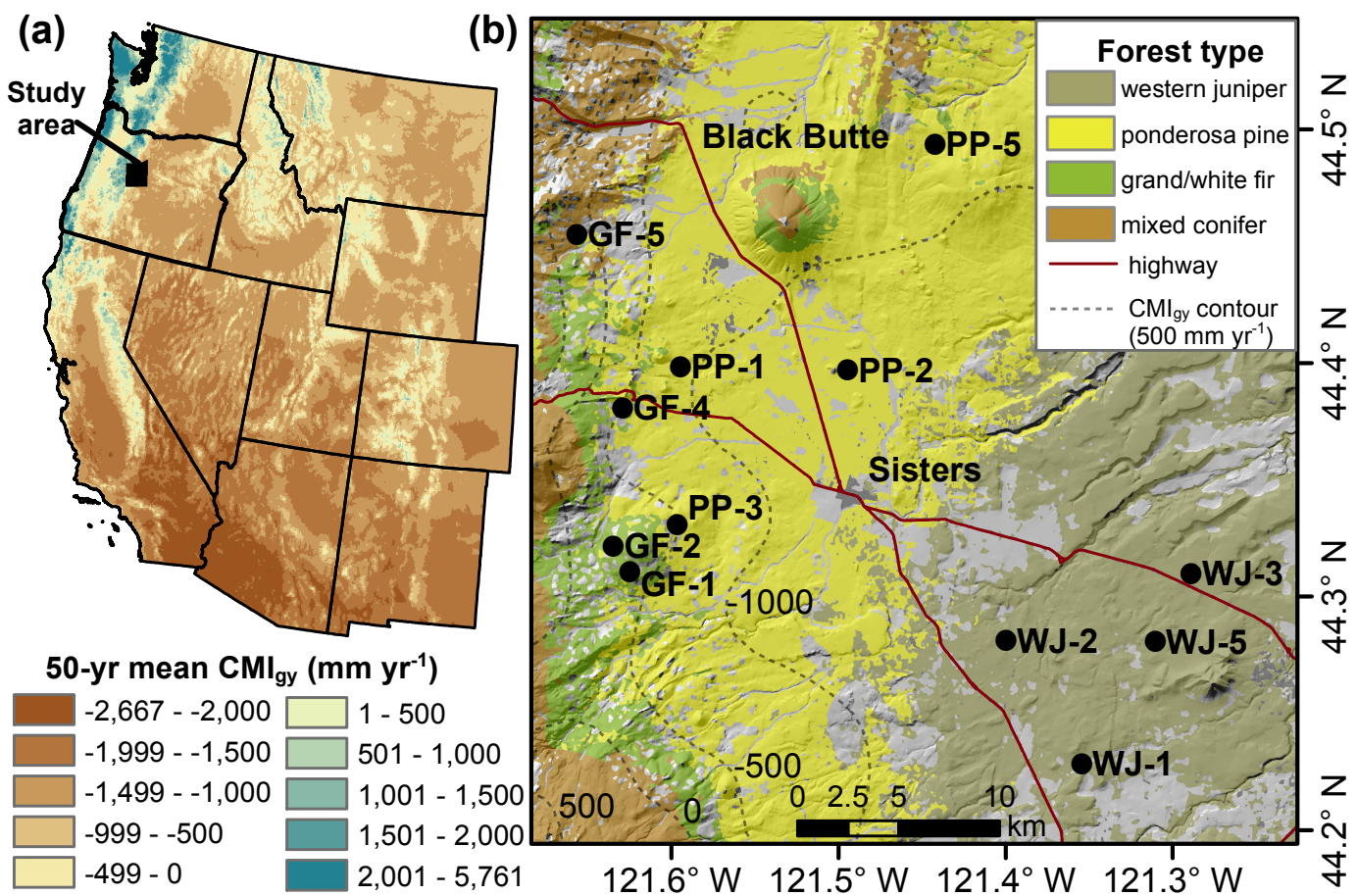

Figure 1. Panel (a): locator map depicting study area location and mean growing-year climate moisture index from 1964 to 2013 (CMI $\overline{\mathrm{gy}}$; $\mathrm{mm} \mathrm{yr}^{-1}$ ) across the western United States. Panel (b): field sites (points) were located in the eastern Cascade Mountains (Oregon) and spanned three forest types that occur along a steep gradient in $\mathrm{CMI}_{\overline{\mathrm{gy}}}$. Contours (dotted lines) depict $\mathrm{CMI}_{\overline{\mathrm{gy}}}$ in $500 \mathrm{~mm} \mathrm{yr}^{-1} \mathrm{increments} \mathrm{We}$ derived $\mathrm{CMI}_{\overline{\mathrm{gy}}}$ from PRISM climate data (Daly et al., 2008), while data on forest type were from Kagan et al. (2006).

that forest leaf area index (LAI), annual aboveground net primary productivity (ANPP), and aboveground live biomass (AGB) would increase with $\mathrm{CMI}_{\overline{g y}}$.

Interannual fluctuations in water availability exert a stronger influence on tree growth in dry, low-elevation forests than in wet, mid-elevation forests. We anticipated that the proportion of trees exhibiting a significant positive correlation between annual tree-ring-width indices (RWI) and CMI over the past 50 years $\left(F_{\mathrm{RWI}-\mathrm{CMI}}\right)$ would be highest among western juniper, followed by ponderosa pine and then grand fir. Furthermore, we predicted that the site-average strength of the RWI-CMI correlation ( $\left.\bar{r}_{\text {RWI-CMI }}\right)$ across years would decrease with increasing $\mathrm{CMI}_{\overline{g y}}$ across sites

Trees respond to increased long-term water availability (i.e., reduced hydraulic stress) by increasing investment of resources to competition for light. We anticipated that average stem wood density $(\overline{\mathrm{WD}})$ would decrease with increased $\mathrm{CMI}_{\overline{\mathrm{gy}}}$, whereas maximum tree height $\left(H_{\max }\right)$ and LA: SA would increase with $\mathrm{CMI}_{\overline{g y}}$.

\section{Materials and methods}

\subsection{Study design}

We employed a gradient analysis that included 12 sites evenly distributed among three forest types (western juniper, ponderosa pine, and grand fir) along the eastern slopes of the Cascade Mountains, Oregon, which ranged in elevation from 929 to $1560 \mathrm{~m}$ above sea level (Fig. 1a, b). Guided by maps of forest type (Kagan et al., 2006), historical wildfires (Eidenshink et al., 2007), and land ownership we selected sites in areas with mature (> 80 years), publicly owned forest that showed minimal evidence of recent natural (e.g., fire, insect) or human disturbance (e.g., thinning). Furthermore, sites were situated within $100 \mathrm{~m}$ of a road to facilitate access. We included the long-term AmeriFlux Metolius Mature Pine (US-Me2) eddy covariance flux tower (Law et al., 2004) as one of our ponderosa pine sites. Additionally, we collected samples at three relatively young stands, one for each species, which included the Metolius Young Pine Burn flux tower site (US-Me6). These data are presented in Table S2, though were not included in our analysis given that the mean cambial age at breast height was 17 to 38 years, depending on site.

At each new site we established a randomly located 1 ha plot, as per the Global Terrestrial Observing System (GTOS) protocol (Law et al., 2008), though used pre-existing plots at US-Me2 and US-Me6. The plot design, similar to that used by the USDA Forest Service Forest Inventory and Analysis program, included one central subplot and three subplots arranged in a circular pattern around the center and offset from the center by $35 \mathrm{~m}$. Subplot radii were held consistent 
within a site but varied among sites from 10 to $17 \mathrm{~m}$ for trees and from 5 to $17 \mathrm{~m}$ for saplings, depending on stem density. Stems with a diameter at breast height (DBH; $1.4 \mathrm{~m})$ greater than $10 \mathrm{~cm}$ were considered trees, while those with DBH from 1 to $10 \mathrm{~cm}$ were considered saplings. We tagged every tree $(n=730)$ and sapling $(n=39)$ in the study with a unique identifier. Seedlings $(\mathrm{DBH}<1 \mathrm{~cm}$ ) were not sampled.

\subsection{Field sampling}

Field activities included stem survey measurements, collection of tree core and foliage samples, and optical measurements of leaf area, as per the GTOS protocol (Law et al., 2008). We measured DBH and total height $(H)$ of every tagged stem and then, within each subplot, randomly selected a subset of trees for intensive measurement. Tree $H$ was measured using a laser range finder (Laser Technology Inc., Centennial, USA).We cored five trees of the dominant species per subplot (20 trees per plot) for growth measurements. Tree cores were extracted near breast height using a $5.15 \mathrm{~mm}$ increment borer and, if necessary, oriented perpendicular to the slope. We then randomly selected 2 or 3 of the 5 trees per subplot (10 trees total per plot) and collected an additional core from each tree for wood density and sapwood area measurements. For each of the 10 intensively measured trees, we also excised mid-canopy, southfacing branches and collected foliage for measurements of leaf longevity (LL), specific leaf area (SLA), and foliar carbon $(\mathrm{C})$ and nitrogen $(\mathrm{N})$. For ponderosa pine and grand fir, we estimated LL on the excised branches using the "counting cohorts" method (Pérez-Harguindeguy et al., 2013). Since western juniper do not form distinct cohorts we calculated LL based on estimates of foliage biomass and annual leaf litter fall from a nearby site (Runyon et al., 1994). Foliage was then stored following standard protocols prior to laboratory analysis (Pérez-Harguindeguy et al., 2013). We collected additional tree cores and foliage samples when nondominant tree species were present in the subplots. The number of additional trees varied from one to six depending on the diversity and relative abundance of additional species. Lastly, we measured the canopy gap fraction on each subplot using an optical LI-2200 Plant Canopy Analyzer for conifers (LICOR, Lincoln, USA).

\subsection{Sample processing}

\subsubsection{Tree cores: radial growth, sapwood area, and stem wood density}

We measured annual radial growth using 256 tree cores, focusing principally on the 50-year period from 1964 to 2013, and estimated tree age on cores that included the pith. The tree cores were processed using standard procedures (Pilcher, 1990). We measured annual ring widths using a desktop scanner and WinDendro software (89\% of cores) or a stereo- scopic microscope, Velmex sliding stage, and MeasureJ2X software if the growth rings were very tight (11\% of cores). We cross-dated the cores visually (Yamaguchi, 1991) and then statistically in $\mathrm{R}$ ( $\mathrm{R}$ Core Team, 2015; version 3.2.0) using the Dendrochronology Program Library in R package (dplR; Bunn, 2010).

We estimated sapwood area and basic stem wood density initially using the same set of tree cores $(n=134)$. Sapwood width was measured using calipers. Sapwood area at breast height was calculated for each sampled tree as the difference between stem basal area (excluding bark) and stem heartwood area, assuming a circular trunk. For each species DBH was a strong predictor of sapwood area $\left(r^{2}=0.85-0.93\right.$; Table S3), and therefore we used these relationships to predict sapwood basal area for trees that were not sampled.

We estimated basic stem wood density following published guidelines (Williamson and Wiemann, 2010), which involved removing the bark, cutting each core into multiple segments and then measuring segment cross-sectional diameter and length using calipers. The core segments were ovendried at $101-105^{\circ} \mathrm{C}$ for $72 \mathrm{~h}$ and then immediately weighed. We calculated basic stem wood density (WD $\mathrm{g} \mathrm{cm}^{-3}$ ) for each core segment by dividing oven-dry mass $(g)$ by the green volume $\left(\mathrm{cm}^{3}\right)$. Since each segment represented a different portion of the total trunk cross-sectional area, we calculated an area-weighted mean WD across segments to account for potential variation in WD between the cambium and the pith (Muller-Landau, 2004).

Williamson and Wiemann (2010) recommended estimating WD from tree cores only when the core includes the pith. Since $25 \%$ of our tree cores $(n=43)$ did not include the pith, we tested, for each species, whether WD estimates differed significantly depending on whether the tree had been or had not been pithed. For fir and pine, the WD estimates did not differ significantly ( $t$ tests, $P>0.05$ ) between samples with or without the pith; however, for juniper, the WD estimates were significantly lower for samples that did not include the pith $(P<0.05)$. We therefore chose to exclude samples from 14 juniper trees that did not include the pith, yet retained all samples from fir and pine irrespective of whether the sample included the pith. In total, we analyzed samples from 120 trees.

\subsubsection{Foliage samples: specific leaf area and chemistry}

We measured SLA (one half of total leaf (i.e., hemisurface area) area per gram of carbon) and leaf chemistry ( $\mathrm{C}$ and N) using samples collected from 186 trees in the middle of the growing season. Mid-growing-season leaf characteristics tend to be representative of species-average conditions (e.g., Nippert and Marshall, 2003). We carefully trimmed the needles from each sample (usually about $0.5 \mathrm{~g}$ dry weight), measured the cumulative projected surface area using a LI-3100C Area Meter (LI-COR, Lincoln, USA), dried each sample at $70^{\circ} \mathrm{C}$ for at least $72 \mathrm{~h}$, and then immediately weighed each 
sample (Pérez-Harguindeguy et al., 2013). Samples were then finely ground and sent to Central Analytical Laboratory at Oregon State University for analysis of $\mathrm{C}$ and $\mathrm{N}$ content using a Leco CNS-2000 Macro Analyzer. We calculated SLA $\left(\mathrm{cm}^{2}\right.$ leaf $\left.\mathrm{g}^{-1} \mathrm{C}\right)$ as

$\mathrm{SLA}=\frac{A \times \beta}{M \times C}$,

where $A$ was the projected surface area $\left(\mathrm{cm}^{2}\right) ; \beta$ was a species-specific conversion coefficient drawn from the literature that related $A$ to one half of total surface area (Table 1); $M$ was oven-dry mass (g); and $C$ was the species-average carbon content of leaf dry matter $(\%)$.

\subsection{Forest leaf area, biomass, and productivity}

\subsubsection{Forest leaf area}

We estimated LAI (one half of surface area of needles $\left(\mathrm{m}^{2}\right)$ per square meter of ground) at 35-45 random points on each subplot based on optical measurements. We used the FV2200 software (LI-COR, Lincoln, USA) to calculate effective leaf area $\left(L_{\mathrm{e}}\right)$ from field measurements of canopy gap fraction, which implemented a foliage scattering and transmittance correction that permits measurements to be made during periods of direct sunlight (Kobayashi et al., 2013). The LAI measurements were subsequently corrected for foliage $(\gamma)$ and canopy clumping $(\Omega)$, as well as for light interception by branches and stems (Chen, 1996; Law et al., 2008). We computed LAI as

$\mathrm{LAI}=L_{e}\left(\frac{\gamma}{\Omega}\right)-W$,

where species-specific $\gamma$ was derived from the literature (Frazer et al., 2000; Law et al., 2001) and $\Omega$ was derived directly from the LI-2200. We calculated wood area index $(W)$ from stand basal area $\left(\mathrm{BA} ; \mathrm{m}^{2} \mathrm{ha}^{-1}\right)$ as

$W=2.061 \times\left(1-e^{(-0.006 \times \mathrm{BA})}\right)$,

based on the strong relationship $\left(r^{2}=0.90\right)$ observed between $W$ and BA across 96 sites in Oregon (Law, unpublished data). For mixed species subplots we calculated a biomass-weighted mean $\gamma$.

\subsubsection{Forest biomass}

We estimated forest AGB $\left(\mathrm{kg} \mathrm{C} \mathrm{m}^{-2}\right)$ for each subplot as the total mass of bole, branch, bark, and leaf carbon of all trees and saplings, divided by the areal extent of each plot. Tree component biomass was computed using species-specific allometric equations based on tree $\mathrm{DBH}$ and $\mathrm{H}$, while sapling biomass was calculated from height alone (Gholz et al., 1979; Means et al., 1994; Wenzel, 1977). Bole volume estimates were converted to dry matter using species-average WD measurements from our study sites. Bole, branch, and bark dry matter were assumed to be $51 \%$ carbon (Law et al., 2001). Leaf mass was computed by dividing LAI by ecosystem-averaged SLA, with ecosystem-average SLA calculated based on the relative biomass of each species present.

\subsubsection{Forest productivity}

We estimated forest ANPP $\left(\mathrm{kg} \mathrm{C} \mathrm{m}^{-2} \mathrm{yr}^{-1}\right)$ biometrically for each site by calculating the change in forest AGB (excluding leaf mass) between 2005 and 2014, divided by the number of intervening years, plus annual leaf turnover (e.g., Hudiburg et al., 2009; Van Tuyl et al., 2005). This necessitated hindcasting DBH and $\mathrm{H}$ for each tree using radial growth measurements and allometric models to predict $\mathrm{H}$ from $\mathrm{DBH}$. We did not collect cores from every tree and therefore we divided the trees at each site into three equal-sized, speciesspecific groups based on DBH. We then took the available ring-width measurements within each size class and calculated the average diameter increment over the preceding 10 years, which was then subtracted from the $\mathrm{DBH}_{2014}$ of each tree in the size class to yield an estimate of $\mathrm{DBH}_{2005}$. For each species we developed a nonlinear Weibull-type model (Yang et al., 1978) to predict H from DBH $\left(r^{2}=0.66-0.87\right.$; RMSE $=1.55-3.21 \mathrm{~m}$; Table S4). We estimated $H_{2005}$ from $\mathrm{DBH}_{2005}$ for each tree and subsequently calculated forest AGB in 2005 (excluding leaf mass) for each subplot. Forest ANPP was then estimated for each subplot by differencing woody AGB from 2014 from that of 2005, divided by the 10 intervening years, plus annual leaf turnover computed by dividing leaf mass in 2014 by ecosystem-average leaf longevity measured at our sites.

\subsection{Climate data and derivation of climate moisture index}

We derived monthly estimates of CMI (Hogg, 1997) for each site as the difference between PPT and $\mathrm{ET}_{0}$ using gridded climate data from 1964 to 2013. The climate data were produced by the Parameter-elevation Relationships on Independent Slopes Model (PRISM; http://www.prism.oregonstate. edu/; Daly et al., 2008) based on climate station observations and spatial modeling at $4 \mathrm{~km}$ resolution. We calculated monthly $\mathrm{ET}_{0}\left(\mathrm{~mm}\right.$ month $\left.^{-1}\right)$ using a version of the Hargreaves equation (Hargreaves and Samani, 1985) modified by Droogers and Allen (2002):

$$
\begin{aligned}
\mathrm{ET}_{0}= & 0.0013 \times 0.408 R\left(T_{\mathrm{avg}}+17.0\right) \\
& \left(T_{\text {rng }}-0.0123 \mathrm{PPT}\right)^{0.76},
\end{aligned}
$$

which is based on average daily extraterrestrial radiation $(R$; $\left.\mathrm{MJ} \mathrm{m}^{-2} \mathrm{~d}^{-1}\right)$, average daily temperature $\left(T_{\text {avg }} ;{ }^{\circ} \mathrm{C}\right)$, daily temperature range $\left(T_{\mathrm{rng}} ;{ }^{\circ} \mathrm{C}\right)$, and precipitation (PPT; mm month ${ }^{-1}$ ). Estimates of $R$ were derived based on equations provided by Allen et al. (1998). Modeled monthly $\mathrm{ET}_{0}$ and PPT agreed relatively well with meteorological measurements at the US-Me2 flux tower site from 2002 to 2012 
Table 1. Species conversion coefficients $(\beta)$ relating leaf projected surface area to one half of total surface area.

\begin{tabular}{llll}
\hline Species & $\beta$ & Source & Notes \\
\hline Western juniper & 1.57 & Hicks and Dugas (1998) & \\
Lodgepole pine & 1.28 & Barclay (1998) & average of values in Table 4 \\
Ponderosa pine & 1.20 & Cregg (1994) & coefficient for western red cedar \\
Incense cedar & 1.14 & Barclay and Goodman (2000) & also used for noble fir \\
Grand fir & 1.09 & Barclay and Goodman (2000) & \\
\hline
\end{tabular}

$\left(r^{2}=0.57-0.64, P<0.01\right)$ and at the US-Me6 flux tower from 2010 to $2013\left(r^{2}=0.58-0.65, P<0.01\right)$. For each site we then summarized climate conditions over the growing year (gy; October in year $t-1$ through September of year $t$ ), which involved calculating average $T_{\text {avg }}$, as well as cumulative PPT, $\mathrm{ET}_{0}$, and CMI (e.g., denoted $\mathrm{CMI}_{\mathrm{gy}}$ ). Lastly, we averaged growing-year climate conditions from 1964 to 2013 to produce 50-year climatologies for each variable (e.g., $\mathrm{CMI} \overline{g y})$.

\subsection{Analyses}

\subsubsection{Constraints of long-term water availability on forest carbon cycling}

For each site we computed the average and standard error (SE) of LAI, ANPP, and AGB among subplots and then examined the relationship between each of the variables and $\mathrm{CMI}_{\overline{g y}}$ across sites. Scatterplots revealed nonlinear relationships between each variable and $\mathrm{CMI}_{\overline{g y}}$, which could be described using power functions $\left(Y=a X^{b}\right)$. Power function models were fit using the nonlinear least squares (nls) function in $R$ (version 3.2.0), and model residuals were visually examined. For each model we calculated the root mean squared error (RMSE) and the coefficient of determination $\left(r^{2}\right)$, which was computed based on the proportion of the total sum of squares explained by the model. We also examined the relationships among forest LAI, ANPP, and AGB using least squares linear regression.

\subsubsection{Influence of interannual fluctuations in water availability on tree radial growth}

We derived standardized tree-ring-width indices (RWI) for each mature tree using functions in dlpR (Bunn, 2010) and then quantified the association between each RWI series and monthly CMI aggregated over the preceding 1 to 36 months. For each tree at least 70 years old $(n=216)$, we subset measurements from 1964 to 2013, detrended the series using a flexible spline and then standardized the series by dividing the ring width in year $t$ by the value predicted for year $t$ by the fitted function (Fritts, 2001). Splines were fit with the detrend function in dplR using a 30-year window and frequency response of 0.5 . Next, we removed lag1 autocorrelation (i.e., pre-whitened) from each RWI series by taking the residuals of an ordinary least squares regression that related the RWI from each year against that of the prior year. We then computed Pearson's correlations between each RWI series and monthly pre-whitened and linearly detrended CMI aggregated from 1 to 36 months. This approach resulted in 432 correlations per tree $(12$ months $\times 36$ lags). For each tree we calculated the overall strength of the RWI-CMI correlation as the average of the $95 \%$ quantile of all computed correlations. We then summarized these responses by both species and site. For each of the three species we calculated the percent of trees that exhibited a significant $(P<0.05)$ positive RWI-CMI correlation at each month $\times$ lag combination. Next, we computed an ecosystemaverage RWI-CMI correlation ( $\left.\bar{r}_{\text {RWI-CMI }}\right)$ for each site, based on the relative biomass of each species, and then examined how $\bar{r}_{\text {RWI-CMI }}$ changed with CMI $\overline{\overline{g y}}_{\text {. }}$. We also tested whether the percent of trees at each site that exhibited a significant RWI-CMI correlation $\left(F_{\text {RWI-CMI }}\right)$ differed among the three forest types using a nonparametric Kruskal-Wallis rank sum test (Kruskal and Wallis, 1952), which assesses the null hypothesis that all samples come from the same distribution. Lastly, we examined the relationship between RWI and other climate variables, including $T_{\text {avg }}, T_{\min }, T_{\max }$, VPD, number of freeze days, the standardized precipitation-evaporation index (SPEI; Vicente-Serrano et al., 2010) and the climatic water deficit (i.e., monthly $\mathrm{ET}_{0}$ in excess of PPT), yet focused on CMI because trees were generally most sensitive to this climate variable. For completeness, we provide summaries of these additional growth-climate relationships in Fig. S1 and Table S6.

\subsubsection{Constraints of long-term water availability on tree morphological traits}

To explore long-term hydraulic constraints on forest morphology we compared LA:SA $\left(\mathrm{m}^{2}\right.$ leaf $\mathrm{cm}^{-2}$ sapwood), $H_{\max }(\mathrm{m})$, and $\overline{\mathrm{WD}}\left(\mathrm{g} \mathrm{cm}^{-3}\right)$ to $\mathrm{CMI}_{\overline{\mathrm{gy}}}$. For each subplot we calculated LA:SA as the ratio between LAI and sapwood basal area, $H_{\max }$ as the height of the tallest tree, and $\overline{\mathrm{WD}}$ as the biomass-weighted average WD of each species present. We then computed the average and SE of each characteristic for each plot. Next, we modeled each trait as a function of $\mathrm{CMI}_{\overline{\mathrm{gy}}}$ using either linear or nonlinear regression. 


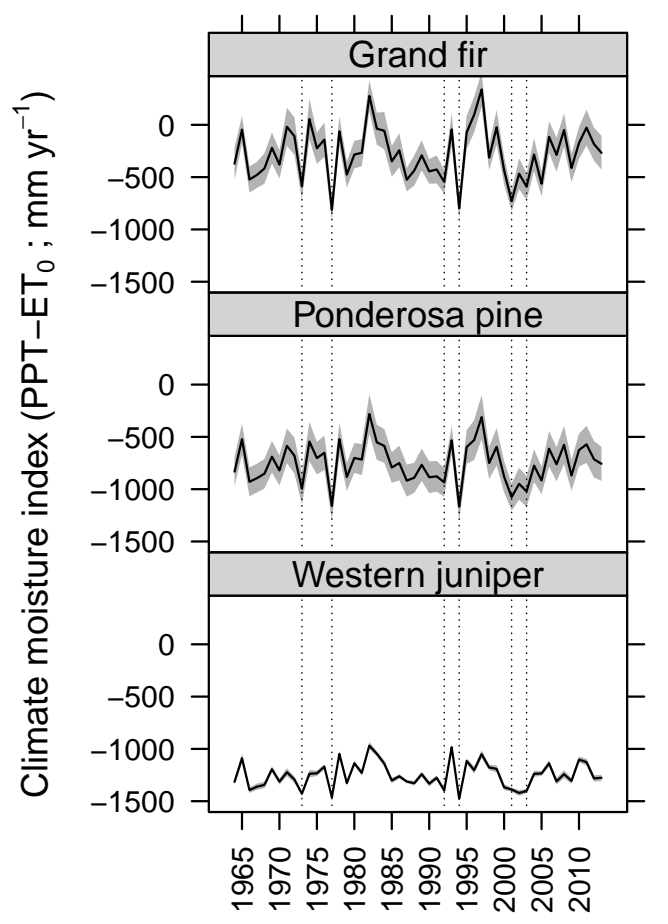

Year

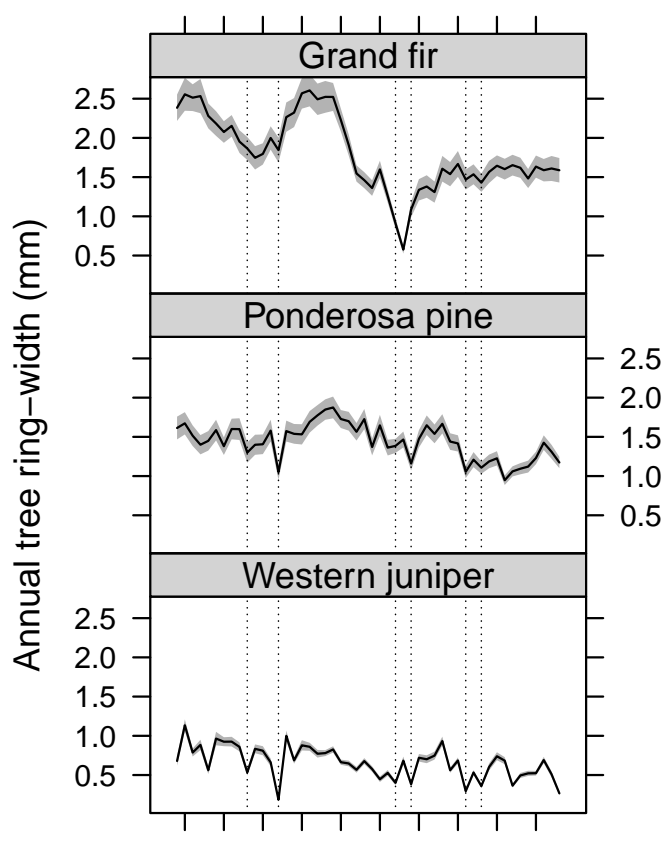

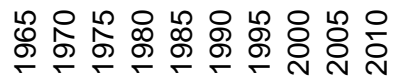

Year

Figure 2. Growing-year climate moisture index $\left(\mathrm{CMI}_{\mathrm{gy}}\right)$ from 1964 to 2013 averaged $( \pm 1 \mathrm{SE})$ across sites $(n=4)$ in three forest types $($ left panel). Average ( $\pm 1 \mathrm{SE})$ annual radial growth at breast height for grand fir $(n=62)$, ponderosa pine $(n=82)$, and western juniper $(n=72)$ from 1964 to 2013, with trees pooled irrespective of site (right panel). In both panels the dotted vertical lines depicted 6 notably dry years (1973, 1977, 1992, 1994, 2001 and 2003) over the 50-year record.

Table 2. Average ( \pm 1 SD) growing-year climate conditions from 1964 to 2013 for sites dominated by western juniper, ponderosa pine, and grand fir in the eastern Cascade Mountains, Oregon. The growing year extended from October of year $t-1$ through September of year $t$. Climate variables include average daily temperature $\left(T_{\mathrm{gy}}\right)$, precipitation $\left(\mathrm{PPT}_{\mathrm{gy}}\right)$, reference evapotranspiration $\left(\mathrm{ET}_{0 \mathrm{gy}}\right)$ and climate moisture index $\left(\mathrm{CMI}_{\mathrm{gy}}=\mathrm{PPT}_{\mathrm{gy}} \mathrm{ET}_{\text {0gy }}\right)$ calculated from monthly PRISM climate data (Daly et al., 2008). We averaged the climate time series for each of the four sites in a given forest type prior to calculating summary statistics.

\begin{tabular}{lllll}
\hline Forest type & $\begin{array}{l}T_{\mathrm{gy}} \\
\left({ }^{\circ} \mathrm{C}\right)\end{array}$ & $\begin{array}{l}\mathrm{PPT}_{\mathrm{gy}} \\
\left(\mathrm{mm} \mathrm{yr}^{-1}\right)\end{array}$ & $\begin{array}{l}\mathrm{ET}_{\text {0gy }} \\
\left(\mathrm{mm} \mathrm{yr}^{-1}\right)\end{array}$ & $\begin{array}{l}\mathrm{CMI}_{\mathrm{gy}} \\
\left(\mathrm{mm} \mathrm{yr}^{-1}\right)\end{array}$ \\
\hline Western juniper & $8.32 \pm 0.80$ & $290 \pm 70$ & $1540 \pm 70$ & $-1250 \pm 120$ \\
Ponderosa pine & $6.90 \pm 0.72$ & $610 \pm 150$ & $1365 \pm 70$ & $-750 \pm 190$ \\
Grand fir & $6.26 \pm 0.72$ & $950 \pm 210$ & $1230 \pm 70$ & $-280 \pm 250$ \\
\hline
\end{tabular}

\section{Results}

\subsection{Climate conditions}

Summary statistics in this section are for 1964 to 2013 and represent cross-site averages $( \pm 1 \mathrm{SD})$ within each of the three forest types (site-level summaries are given in Table S5). Average $T_{\overline{g y}}$ decreased from $8.32 \pm 0.80^{\circ} \mathrm{C}$ at the juniper sites to $6.26 \pm 0.72{ }^{\circ} \mathrm{C}$ at the fir sites, while $\mathrm{CMI}_{\overline{\mathrm{gy}}}$ increased from $-1250 \pm 120$ to $-280 \pm 250 \mathrm{~mm} \mathrm{yr}^{-1}$ (Table 2). Across forest types, July was the climatically driest month, while December, conversely, was the climatically wettest month. At juniper sites, CMI tended to be negative (i.e., $\mathrm{ET}_{0}$ exceeded PPT) for 9 consecutive months each year (February-October), whereas CMI was generally negative at pine and fir sites for 8 (March-October) and 7 (AprilOctober) consecutive months, respectively.

Large interannual fluctuation in $\mathrm{CMI}_{\mathrm{gy}}$ occurred between 1964 and 2013 (Fig. 2 left panel). For instance, 1982 and 1997 were abnormally wet, whereas 1977 and 1994 were abnormally dry. At the juniper sites, $\mathrm{CMI}_{\mathrm{gy}}$ during these wet years was around $300-400 \mathrm{~mm}$ greater than during the dry years. At the fir sites the difference in $\mathrm{CMI}_{\mathrm{gy}}$ between these abnormally wet and dry years was more pronounced, exceeding $1000 \mathrm{~mm}$. Other notable dry years included 1973, 1992, 
2001 and 2003. Conditions were consistently drier than normal from 1985 to 1994 , with $\mathrm{CMI}_{\mathrm{gy}}<\mathrm{CMI}_{\mathrm{gy}}$ for 8 or 9 years, depending on forest type (Fig. S2 in Supplement).

\subsection{Constraints of long-term water availability on forest carbon cycling}

The 12 sites spanned a gradient in $\mathrm{CMI}_{\overline{\mathrm{gy}}}$ from $-1240 \pm 120$ to $50 \pm 290 \mathrm{~mm} \mathrm{yr}^{-1}$, and across this gradient forest LAI, ANPP, and AGB increased significantly $(P<0.05)$ and nonlinearly with $\mathrm{CMI}_{\overline{\mathrm{gy}}}$, which explained $67-88 \%$ of the variability in these stand characteristics (Fig. 3; Table 3, S2, S5). After accounting for wood interception and clumping, LAI ranged from $0.09 \pm 0.03$ to $6.15 \pm 1.12$ across sites, with average $( \pm 1 \mathrm{SD})$ LAI in each forest type increasing progressively from the open-canopy juniper sites $(0.26 \pm 0.13)$ to the pine $(1.92 \pm 0.51)$ and then closed-canopy fir sites (4.54 \pm 1.49 ; Fig. 3a; Table 4). Annual productivity along this gradient increased from $11 \pm 2$ to $311 \pm 60 \mathrm{~g} \mathrm{C} \mathrm{m}^{-2} \mathrm{yr}^{-1}$ and averaged $17 \pm 4,185 \pm 62$, and $238 \pm 54 \mathrm{~g} \mathrm{C} \mathrm{m}^{-2} \mathrm{yr}^{-1}$ at the juniper, pine and fir sites, respectively (Fig. 3b). Aboveground biomass also tended to be quite low at the juniper sites $\left(2.6 \pm 0.4 \mathrm{~kg} \mathrm{C} \mathrm{m}^{-2}\right)$, yet reached higher levels at sites dominated by pine $\left(10.6 \pm 4.1 \mathrm{~kg} \mathrm{C} \mathrm{m}^{-2}\right)$ and fir $\left(14.4 \pm 5.9 \mathrm{~kg} \mathrm{C} \mathrm{m}^{-2}\right)$. Across sites there was a significant $(P<0.01)$ positive linear relationship between LAI and ANPP $\left(r^{2}=0.75\right)$. Furthermore, AGB was positively associated with both LAI $\left(r^{2}=0.57\right)$ and ANPP $\left(r^{2}=0.68\right.$; Table 3).

\subsection{Influence of interannual fluctuations in water availability on tree radial growth}

Annual radial growth varied considerably from 1964 to 2013 (Fig. 2 right panel) and tracked CMI more closely at the chronically dry juniper sites than at the wetter pine and fir sites (Figs. 4, 5). Growth reductions in response to singleyear drought events (e.g., 1977, 1994, and 2001) were evident at the juniper sites, whereas reductions were more modest at the pine and fir sites (Fig. 2 right panel). For instance, the 1977 drought led to a $73 \%$ reduction in average radial growth among juniper in comparison to growth during $1976(0.66 \pm 0.05$ vs. $0.18 \pm 0.03 \mathrm{~mm})$. In contrast, this drought drove a $35 \%$ reduction in average growth among pine $(1.74 \pm 0.14$ vs. $1.08 \pm 0.10 \mathrm{~mm})$ and a $7 \%$ reduction among fir ( $1.87 \pm 0.14$ vs. $1.74 \pm 0.14 \mathrm{~mm})$.

The vast majority of juniper $(91 \pm 3 \%)$ exhibited a significant positive RWI-CMI correlation $\left(\bar{r}_{\text {RWI-CMI }}=0.52 \pm 0.02\right)$ and responded most strongly to CMI over the 6 to 12 months leading up to late spring and summer (Fig. 4a; Table S6). Around $51 \pm 6 \%$ of pine $\left(\bar{r}_{\mathrm{RWI}-\mathrm{CMI}}=0.27 \pm 0.02\right)$ and $12 \pm 4 \%$ of fir ( $\left.\bar{r}_{\text {RWI-CMI }}=0.11 \pm 0.02\right)$ also exhibited a significant positive correlation with CMI, yet the influence of CMI seasonality and timescale were less distinct than for juniper (Fig. 4b, c). The proportion of trees exhibiting a signif-
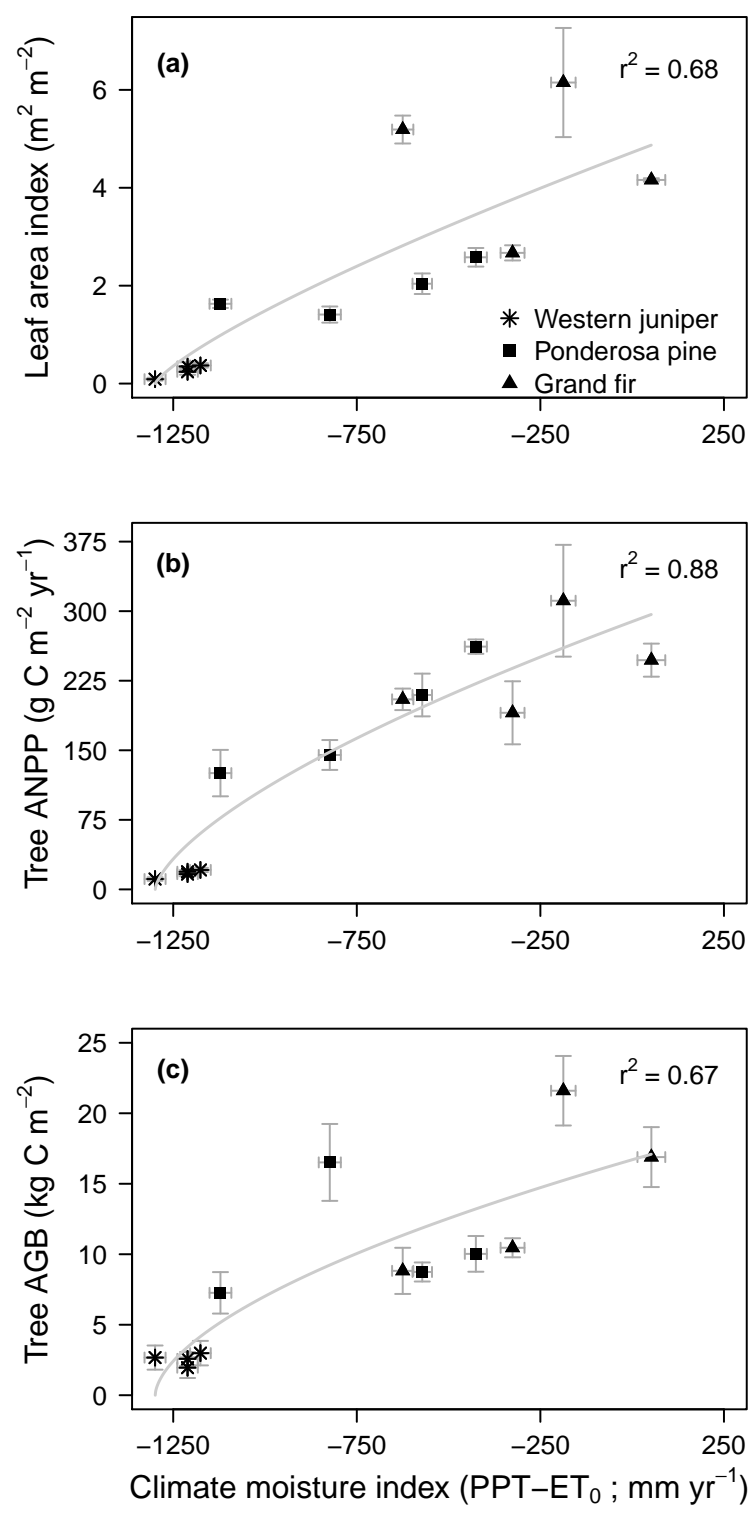

Figure 3. Forest community (a) leaf area index, (b) 10-year average annual aboveground net primary production and (c) aboveground live biomass plotted against the average growing-year climate moisture index from 1964 to $2013\left(\mathrm{CMI}_{\overline{g y}}\right)$ for 12 mature conifer sites in the eastern Cascade Mountains, Oregon. We calculated $\mathrm{CMI}_{\overline{g y}}$ by summing monthly precipitation (PPT) minus reference evapotranspiration $\left(\mathrm{ET}_{0}\right)$ from October to through September and then averaged the growing-year values from 1964 to 2013. Each point represents the mean $( \pm 1 \mathrm{SE})$ of four subplots. Regression coefficients are given in Table 3.

icant RWI-CMI association differed significantly among the three forest types (Kruskal-Wallis, $X^{2}=8.77, P=0.01$ ), and among sites there was a significant negative relationship between $\bar{r}_{\mathrm{RWI}-\mathrm{CMI}}$ and $\mathrm{CMI} \mathrm{I}_{\mathrm{gy}}\left(r^{2}=0.53, P<0.05\right)$, with $\bar{r}_{\text {RWI-CMI }}$ decreasing from $0.57 \pm 0.14$ to $-0.02 \pm 0.07$ as conditions became wetter (Fig. 5). There was a very 


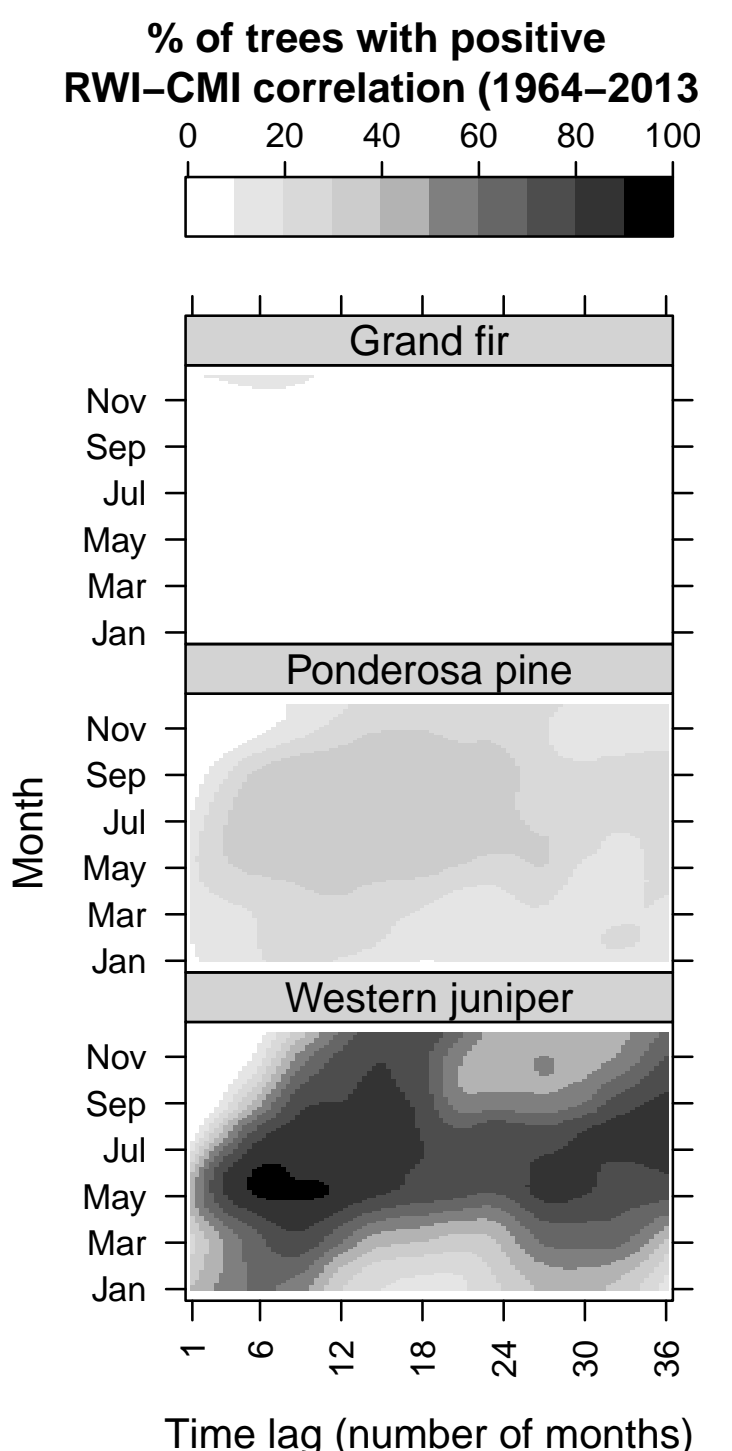

Figure 4. Correlations between annual tree radial growth and the climate moisture index $\left(\mathrm{CMI}=\mathrm{PPT}_{-\mathrm{ET}_{0}}\right)$ from 1964 to 2013 for three tree species in the eastern Cascades, Oregon. Depicted is the proportion of trees with a significant positive correlation between annual ring-width indices (RWI) and CMI calculated for each month at time lags extending from 1 to 36 months. See Fig. S1 and Table S6 for correlations between RWI and additional climate variables.

strong linear relationship between $\bar{r}_{\mathrm{RWI}}$-CMI and $F_{\mathrm{RWI}-\mathrm{CMI}}$ across sites $\left(r^{2}=0.92, P<0.001\right)$. Significant proportions of western juniper and, to a lesser extent, ponderosa pine also showed negative correlations between growth and VPD, $T_{\max }$, climatic water deficit, as well as positive correlations with SPEI, while grand fir were largely unresponsive to any of the climate variables that we examined (Fig. S1; Table S6).

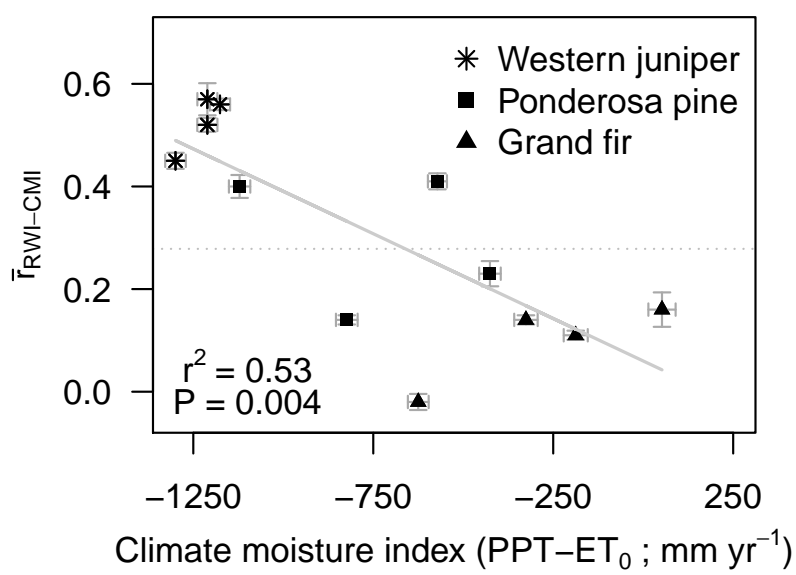

Figure 5. Mean ecosystem-weighted correlation (RWI-CMI) between annual tree-ring-width indices (RWI) and the climate moisture index $\left(\mathrm{CMI}=\mathrm{PPT}-\mathrm{ET}_{0}\right)$ plotted against the 50-year mean ( $\pm 1 \mathrm{SE}$ ) growing-year CMI. The dashed horizontal line denotes statistical significance at $\alpha=0.05$. The 12 sites were located in the eastern Cascade Mountains and represented forest types dominated by western juniper, ponderosa pine and grand fir. Regression coefficients are given in Table 3.

Each species showed relatively high growth around 1980 to 1984 , followed by a general decline from c. 1985 to 1994 (Fig. 2, right panel) that corresponded with a period of relatively sustained, below-average $\mathrm{CMI}_{\mathrm{gy}}$ (Fig. 2, left panel) and, as discussed below, a widespread western spruce budworm (Choristoneura freemani) outbreak. The growth decline was particularly severe among fir; average radial growth in $1993(0.55 \pm 0.04 \mathrm{~mm})$ and 1994 $(1.00 \pm 0.09 \mathrm{~mm})$ was 73 and $52 \%$ lower, respectively, than in $1985(2.07 \pm 0.14 \mathrm{~mm})$. In contrast, pine growth was $38 \%$ lower $(1.23 \pm 0.09 \mathrm{~mm}$ vs. $1.83 \pm 0.12 \mathrm{~mm})$ and juniper growth $42 \%$ lower $(0.38 \pm 0.03 \mathrm{~mm}$ vs. $0.66 \pm 0.03 \mathrm{~mm})$ in 1994 than in 1985. Since disturbances can obscure RWIclimate relationship, we reevaluated the correlations using measurements from 1994 to 2013 and found that the correlations changed little in comparison to those computed from 1964 to 2013 (Table S6).

\subsection{Constraints of long-term water availability on tree morphological traits}

Notable changes in morphological traits were evident along the water availability gradient (Fig. 6a, b, c; Tables 3, 4 , S1). In general, ecosystem-average stem wood density, $\overline{\mathrm{WD}}$, decreased with increased $\mathrm{CMI}_{\overline{g y}}\left(r^{2}=0.36\right.$, Fig. 6a). Correspondingly, species-average stem WD of juniper $\left(0.47 \pm 0.02 \mathrm{~g} \mathrm{~cm}^{-3}\right)$ was $4 \%$ higher than that of pine $\left(0.45 \pm 0.02 \mathrm{~g} \mathrm{~cm}^{-3}\right)$ and $18 \%$ higher than that of fir $\left(0.40 \pm 0.03 \mathrm{~g} \mathrm{~cm}^{-3}\right)$. Maximum tree height increased nonlinearly by $220 \%$ with $\mathrm{CMI}_{\overline{g y}}\left(r^{2}=0.69\right)$, from average $H_{\max }$ of $10.54 \pm 0.53 \mathrm{~m}$ at the juniper sites to $33.54 \pm 5.56 \mathrm{~m}$ 
Table 3. Regression equations relating forest community carbon cycling, morphological characteristics, and long-term (1964-2013) mean growing-year climate moisture index $\left(\mathrm{CMI}_{\overline{\mathrm{gy}}} ; \mathrm{mm} \mathrm{yr}^{-1}\right)$ across 12 sites in the eastern Cascade Mountains, Oregon. Forest characteristics include leaf area index (LAI; half of total surface area; $\mathrm{m}^{2}$ leaf $\mathrm{m}^{-2}$ ground), annual aboveground net primary productivity (ANPP; $\mathrm{g}$ $\mathrm{C} \mathrm{m}^{-2} \mathrm{yr}^{-1}$ ), aboveground live biomass (AGB; $\mathrm{kg} \mathrm{C} \mathrm{m}{ }^{-2}$ ), leaf: sapwood area ratio (LA : SA; $\mathrm{m}^{2}$ leaf $\mathrm{cm}^{-2}$ sapwood), maximum tree height $\left(H_{\mathrm{max}} ; \mathrm{m}\right)$, and average stem wood density $\left(\overline{\mathrm{WD}} ; \mathrm{g} \mathrm{cm}^{-3}\right)$. Also included are the community-average correlation between tree-ringwidth indices (RWI) and CMI from 1964 to 2013 ( $\bar{r}_{\text {RWI-CMI }}$; unitless) and the fraction of individual trees in the community that exhibited a significant $(P<0.05)$ positive RWI-CMI correlation $\left(\bar{r}_{\mathrm{RWI}-\mathrm{CMI}} ; \%\right)$. Equations are either power form $\left(Y=a X^{b}\right)$ or linear $(Y=a+b X)$, where $a$ and $b$ are fitted coefficients, with $X$ and $Y$ in units provided above.

\begin{tabular}{lllrrrrrrr}
\hline Explanatory & Response & Form & $a$ & $a(\mathrm{SE})$ & $b$ & $b(\mathrm{SE})$ & $r^{2}$ & $P$ & RMSE \\
\hline CMI $_{\text {gy }}$ & LAI & power & 0.02 & 0.03 & 0.79 & 0.30 & 0.68 & 0.025 & 1.08 \\
& ANPP & power & 2.47 & 2.23 & 0.66 & 0.13 & 0.88 & 0.001 & 35.7 \\
& AGB & power & 0.24 & 0.33 & 0.59 & 0.20 & 0.67 & 0.014 & 3.52 \\
& $\bar{r}_{\text {RWI-CMI }}$ & linear & 0.02 & 0.07 & -0.00037 & 0.00008 & 0.65 & 0.001 & 0.11 \\
& $F_{\text {RWI-CMI }}$ & linear & 4.90 & 13.10 & -0.07 & 0.02 & 0.63 & 0.001 & 20.32 \\
& LA : SA & linear & 0.29 & 0.03 & 0.00018 & 0.00003 & 0.76 & 0.001 & 0.05 \\
& $H_{\text {max }}$ & power & 4.25 & 2.25 & 0.30 & 0.08 & 0.69 & 0.004 & 5.61 \\
& WD & linear & 0.41 & 0.01 & -0.00005 & 0.00002 & 0.36 & 0.002 & 0.02 \\
& ANPP & linear & 42.05 & 23.97 & 46.82 & 8.11 & 0.75 & 0.002 & 49.51 \\
LAI & AGB & linear & 3.66 & 1.85 & 2.48 & 0.63 & 0.57 & 0.003 & 3.83 \\
& AGB & linear & 1.84 & 1.81 & 0.05 & 0.01 & 0.68 & 0.001 & 3.23 \\
ANPP & $F_{\text {RWI-CMI }}$ & linear & 2.08 & 5.53 & 174.97 & 15.29 & 0.92 & $<0.001$ & 9.34 \\
$\bar{r}_{\text {RWI-CMI }}$ & LA $:$ SA & linear & 0.67 & 0.15 & -1.32 & 0.35 & 0.55 & 0.003 & 0.03 \\
WD & $H_{\text {max }}$ & linear & 118.14 & 36.20 & -214.39 & 82.23 & 0.35 & 0.026 & 8.12 \\
& & & & & & & & \\
\hline
\end{tabular}

Table 4. Summary of carbon cycling, growth-climate, morphological, and chemical characteristics for three conifer species in the eastern Cascade Mountains, Oregon. Both stand- and tree-level characteristics are included. Excluding specific leaf area (SLA), the full name of each characteristic is given in Table 2. The stand-level characteristics provided for grand fir actually represent an average mixture of two thirds grand fir and one third ponderosa pine. The mean, standard deviation, and sample size are provided for each characteristic. Specific leaf area is presented here in terms of leaf hemisurface area and not projected surface area.

\begin{tabular}{|c|c|c|c|c|c|}
\hline \multirow[t]{2}{*}{ Characteristic } & \multirow[t]{2}{*}{ Level } & \multirow[t]{2}{*}{ Units } & \multicolumn{3}{|c|}{ Species } \\
\hline & & & Western juniper & Ponderosa pine & Grand fir \\
\hline LAI & Stand & $\mathrm{m}^{2} \mathrm{~m}^{-2}$ & $0.26 \pm 0.13$ & $1.92 \pm 0.51$ & $4.54 \pm 1.49(4)$ \\
\hline ANPP & Stand & $\mathrm{g} \mathrm{C} \mathrm{m}^{-2} \mathrm{yr}^{-1}$ & $17 \pm 4(4)$ & $185 \pm 62$ & $238 \pm 54(4)$ \\
\hline AGB & Stand & $\mathrm{kg} \mathrm{Cm}^{-2}$ & $2.6 \pm 0.4(4)$ & $10.6 \pm 4.1(4)$ & $14.4 \pm 5.9(4)$ \\
\hline $\bar{r}_{\text {RWI-CMI }}$ & Stand & unitless & $0.52 \pm 0.18$ & $0.27 \pm 0.21(82)$ & $0.11 \pm 0.13(62)$ \\
\hline$F_{\mathrm{RWI}-\mathrm{CMI}}$ & Stand & $\%$ & $91 \pm 3(72)$ & $51 \pm 6(82)$ & $12 \pm 4(62)$ \\
\hline LA : SA & Stand & $\mathrm{cm}^{2} \mathrm{~m}^{-2}$ & $0.08 \pm 0.03(4)$ & $0.12 \pm 0.03$ & $0.28 \pm 0.03$ \\
\hline$H_{\max }$ & Stand & $\mathrm{m}$ & $10.5 \pm 0.5(4)$ & $27.9 \pm 5.3(4)$ & $33.5 \pm 5.6(4)$ \\
\hline WD & Tree & $\mathrm{g} \mathrm{cm}^{-3}$ & $0.47 \pm 0.02$ & $0.45 \pm 0.02(52)$ & $0.40 \pm 0.03(36)$ \\
\hline SLA & Tree & $\mathrm{cm}^{2}$ leaf $\mathrm{g}^{-1} \mathrm{C}$ & $63 \pm 6(40)$ & $91 \pm 11(47)$ & $100 \pm 16(42)$ \\
\hline Leaf longevity & Tree & years & $5.6^{*}$ & $4.3 \pm 1.0(59)$ & $9.2 \pm 2.1(50)$ \\
\hline Leaf $\mathrm{C}$ & Tree & $\%$ & $48.2 \pm 0.8(40)$ & $48.3 \pm 0.5(47)$ & $47.8 \pm 0.5(42)$ \\
\hline Leaf $\mathrm{N}$ & Tree & $\%$ & $0.89 \pm 0.13(40)$ & $1.14 \pm 0.12(47)$ & $0.83 \pm 0.13(42)$ \\
\hline Leaf $\mathrm{C}: \mathrm{N}$ & Tree & unitless & $55 \pm 9(40)$ & $43 \pm 4(47)$ & $59 \pm 10(42)$ \\
\hline
\end{tabular}

* Western juniper leaf longevity was calculated as the ratio of foliage biomass to annual leaf fall using measurements from Runyon et al. (1994).

at the fir-dominated sites (Fig. 6b). Many of the tallest trees at the fir-dominated sites were actually old pine, the tallest of which reached $41.2 \mathrm{~m}$. Forest LA:SA also increased with $\mathrm{CMI}_{\overline{g y}}\left(r^{2}=0.76\right.$; Fig. 6c), ranging from $0.02 \pm 0.01$ to $0.19 \pm 0.02 \mathrm{~m}^{2} \mathrm{~cm}^{-2}$. Average LA: SA was quite low at the juniper sites $\left(0.04 \pm 0.02 \mathrm{~m}^{2} \mathrm{~cm}^{-2}\right)$ and 75 and $300 \%$ higher at the pine $\left(0.07 \pm 0.02 \mathrm{~m}^{2} \mathrm{~cm}^{-2}\right)$ and fir sites $\left(0.16 \pm 0.02 \mathrm{~m}^{2} \mathrm{~cm}^{-2}\right)$, respectively. Lastly, there were significant relationships among $H_{\max }, \overline{\mathrm{WD}}$, and LA:SA across sites $\left(r^{2}=0.35-0.55, P<0.05\right.$; Table 3$)$. 

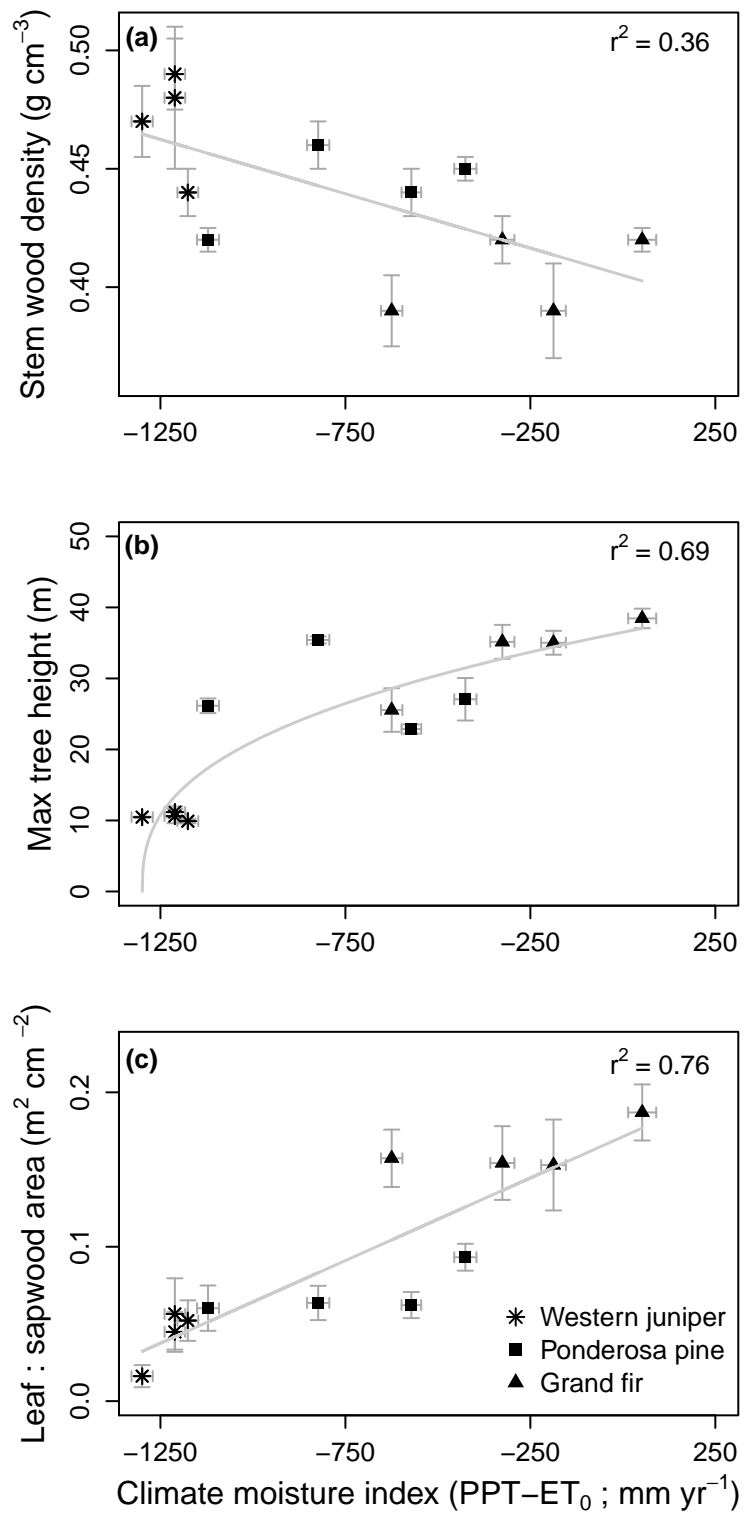

Figure 6. Forest ecosystem (a) average stem wood density, (b) maximum tree height, and (c) leaf: sapwood area ratio plotted against the average growing-year climate moisture index from 1964 to 2013 $\left(\mathrm{CMI}_{\overline{\mathrm{gy}}}\right)$. Each point represents the mean $( \pm 1 \mathrm{SE})$ of four subplots sampled at each site. Regression coefficients are given in Table 3.

\section{Discussion and conclusions}

\subsection{Constraints of long-term water availability on forest carbon cycling}

Consistent with predictions from our first hypothesis, forest ecosystem LAI, ANPP, and AGB increased with CMI ${ }_{\overline{g y}}$, yet residual variance in the regression models implies that the characteristics were influenced by additional bioclimatic or disturbance-related factors. Our results, along with those of several prior field studies (Gholz, 1982; Grier and Run- ning, 1977), indicate that water availability is the dominant constraint on forest leaf area of mature stands in the eastern Cascades. The constraint of water availability on forest leaf area in this environment is driven by the need to maximize carbon assimilation while simultaneously minimizing water loss. Net carbon uptake by trees (i.e., photosynthesisrespiration) occurs within the limits of the hydraulic system (Ruehr et al., 2014), minimizing the risk of embolism when evaporative demand exceeds supply (Meinzer et al., 2010). While $\mathrm{CMI}_{\overline{g y}}$ explained $68 \%$ of the observed variance in LAI, differences among sites in soil nitrogen, stand age, and disturbance history (e.g., windthrow, insect outbreaks) might account for some of the residual variance (Gholz, 1982; Law et al., 2003). For instance, we observed low-level leaf herbivory at several of the grand fir sites, possibly due to western spruce budworm, which has affected large areas of forest in this region over the past 3 decades (Meigs et al., 2015; Willamette National Forest, 1995). Defoliation could have temporarily reduced leaf area without killing the trees, drawing down stored carbohydrates during refoliation. Additionally, there is uncertainty in both destructive and nondestructive estimates of forest leaf area (Law et al., 2001; Runyon et al., 1994) that could have further obscured the relationship with long-term climate. For example, summer maximum LAI at the Metolius Mature Pine flux site averaged about 2.5 over the past 8 years, starting around 2.1 in 1997 (Law et al., 2001), and our estimate for 2014 was about 2.0. The substantial increase in forest leaf area from the dry western juniper woodlands to the more mesic grand fir forests highlights the importance of long-term water availability in controlling light-harvesting potential and subsequent carbon accumulation.

Forest productivity is highly dependent on leaf area (Gholz, 1982; Waring, 1983; Waring et al., 2014) and therefore the observed increase in forest ANPP with $\mathrm{CMI}_{\overline{g y}}$ can be largely explained by the concomitant increase in leaf area. Forest leaf area and $\mathrm{CMI}_{\overline{g y}}$ respectively explained $75 \%$ and $88 \%$ of the variation in ANPP across sites. Forest leaf area largely determines the interception of photosynthetically active radiation (IPAR; Runyon et al., 1994), while subsequent utilization of IPAR for photosynthesis depends on physiological constraints imposed by environmental conditions (Landsberg and Waring, 1997; Runyon et al., 1994; Tezara et al., 1999). For instance, Runyon et al. (1994) found at seven sites in Oregon that annual IPAR increased linearly with LAI $\left(r^{2}=0.95\right)$, while subsequent ANPP depended on utilized IPAR $\left(r^{2}=0.99\right)$, which was calculated by reducing IPAR based on constraints imposed due to low soil moisture, high VPD, and the duration of subfreezing temperatures. Differences in biotic and abiotic constraints among our sites could explain some of the remaining variance in the ANPP-CMI $\mathrm{Cy}_{\mathrm{g}}$ relationship (e.g., summer VPD, extent of freezing days each year, soil fertility and ratio of above- to belowground $\mathrm{C}$ allocation; Schwarz et al., 2004). 
Our estimates of ANPP for ponderosa pine over the past 10 years (125-262 $\mathrm{g} \mathrm{C} \mathrm{m}^{-2} \mathrm{yr}^{-1}$ ) were within the range reported by Law et al. (2003) for six mature to old stands (103$473 \mathrm{~g} \mathrm{C} \mathrm{m}^{-2} \mathrm{yr}^{-1}$ ) in the region and agreed to within $14 \%$ at the Mature Pine flux tower site $(210 \pm 23$ vs. $242 \pm 57 \mathrm{~g}$ $\mathrm{C} \mathrm{m}^{-2} \mathrm{yr}^{-1}$ ). Productivity at our four ponderosa pine sites was about 20-60\% higher than at sites examined by Gholz (1982; $\left.\approx 110 \mathrm{~g} \mathrm{C} \mathrm{m}^{-2} \mathrm{yr}^{-1}\right)$ and Runyon et al. (1994; $\approx 95 \mathrm{~g}$ $\left.\mathrm{C} \mathrm{m}^{-2} \mathrm{yr}^{-1}\right)$, whereas ANPP at our western juniper sites (11-21 $\mathrm{g} \mathrm{C} \mathrm{m}^{-2} \mathrm{yr}^{-1}$ ) was considerably lower than at sites examined by either $\operatorname{Gholz}\left(1982 ; \approx 60 \mathrm{~g} \mathrm{C} \mathrm{m}^{-2} \mathrm{yr}^{-1}\right)$ or Runyon et al. (1994; $\approx 80 \mathrm{~g} \mathrm{C} \mathrm{m}^{-2} \mathrm{yr}^{-1}$ ). Spatial differences in soil-water-holding capacity in the rocky volcanic soils (Peterman et al., 2013) could account for some of the discrepancy in productivity, as could differences in stand density or age. Western juniper at our sites were generally quite old and had accumulated considerably higher overall AGB $(2-3 \mathrm{~kg}$ $\mathrm{C} \mathrm{m}^{-2}$ vs. $\approx 0.5 \mathrm{~kg} \mathrm{C} \mathrm{m}^{-2}$ ). Overall, forest ANPP increased with long-term average water availability, largely owing to the increased leaf area but potentially also due to reductions in abiotic constraints on carbon assimilation.

Forest AGB reflects the long-term integration of ANPP minus carbon loss (e.g., litterfall, herbivory, tree mortality), and therefore higher biomass observed at wetter sites was likely driven by higher rates of ANPP sustained over centennial timescales. Forest AGB increased with $\mathrm{CMI}_{\overline{g y}}\left(r^{2}=\right.$ 0.67 ) and achieved a carbon density, when averaged across the grand fir sites, that was $6 \%$ greater than the average AGB estimated for temperate forests worldwide $\left(\approx 13.5 \mathrm{~kg} \mathrm{C} \mathrm{m}^{-2}\right.$; Houghton et al., 2009). We found that $\mathrm{CMI}_{\overline{g y}}$ explained less of the variance in forest AGB than ANPP $\left(r^{2}=0.88\right)$, potentially as a result of differences among sites in tree mortality rates. For instance, there was little sign of recent tree mortality at the western juniper or ponderosa pine sites, yet there were several large, freshly wind-thrown trees at two of the grand fir sites (GF-1 and GF-4) that could somewhat account for lower AGB at these sites $\left(8.8-10.4 \mathrm{~kg} \mathrm{C} \mathrm{m}^{-2}\right.$ ) compared with the other two grand fir sites $(16.9-21.6 \mathrm{~kg}$ $\mathrm{C} \mathrm{m}^{-2}$ ). Additionally, differences among sites in growth impairment and mortality from periodic, historic outbreaks of spruce budworm and mountain pine beetle (Dendroctonus ponderosae; Meigs et al., 2015) could account for some of the unexplained variance in the $\mathrm{AGB}-\mathrm{CMI}_{\overline{\mathrm{gy}}}$ regression model. Our findings, and those of prior field (Franklin and Dyrness, 1988; Gholz, 1982; Grier and Running, 1977) and modeling (Kang et al., 2014; Runyon et al., 1994) analyses, demonstrate that steep gradients in water availability are a key factor shaping forest distribution and carbon cycling in the Pacific Northwest, with regional forests further molded by disturbances such as timber harvest, wildfire, and insect outbreaks (Law et al., 2004; Law and Waring, 2015; Meigs et al., 2015).

\subsection{Influence of interannual fluctuations in water availability on tree radial growth}

We found evidence to support the hypothesis that interannual fluctuation in water availability exerted less influence over tree growth as conditions became wetter; however, we unexpectedly observed a pronounced growth decline across species from c. 1985 to 1994 that was particularly severe among grand fir and potentially associated with relatively sustained, dry conditions over that decade. We observed that as $\mathrm{CMI}_{\overline{g y}}$ increased, there was a decline in the proportion of trees at each site that showed a significant correlation between radial growth and CMI as well as a decline in the magnitude of that correlation. This suggests that, on an annual basis, water tends to limit the growth of western juniper to a greater extent than that of either ponderosa pine or grand fir, a finding consistent with results from a modeling study that showed that drought imposed greater physiological reductions on the utilization of annual IPAR by western juniper than by ponderosa pine or other conifers at higher elevations in the eastern Cascade Mountains (Runyon et al., 1994). Western juniper trees occupy sites with chronically low rainfall, high summer VPD and ET, and often thin, rocky soils, leading to generally low soil moisture that is highly dependent on annual recharge. Thus, annual photosynthesis and subsequent stem wood production of western juniper track the annual water balance to a greater extent than ponderosa pine or grand fir, which occupy sites with not only higher rainfall but reduced summer VPD and ET. Furthermore, soils in the ponderosa pine and grand fir zones tend to be deeper and have greater water storage capacity than in the western juniper zone (Kern, 1995). Soil depth averaged about $0.5 \mathrm{~m}$ at a nearby juniper site (Anthoni et al., 1999) and about $2 \mathrm{~m}$ at the Metolius Mature Pine site (Law, unpublished data). Our analysis focused on changes in tree growth-climate relations over tens of kilometers, yet evidence from tree-ring and remote-sensing analyses at regional (Huang et al., 2015; Littell et al., 2008; Wilmking and Juday, 2005), hemispheric (Vicente-Serrano et al., 2014) and global scales (VicenteSerrano et al., 2013) suggests that as landscapes become wetter, annual tree growth generally becomes increasingly decoupled from interannual fluctuations in water availability. Nevertheless, trees in characteristically wet landscapes can still be vulnerable to drought-induced stress and mortality (Allen et al., 2010).

What factor, or complex of factors, were responsible for the notable cross-species decline in tree radial growth from c. 1985 to 1994 , and why was the decline most severe in grand fir? Ponderosa pine at low and high elevations in southern Oregon also experienced reduced growth during these years (Knutson and Pyke, 2008). This 10-year period was characterized by 9 years in which $\mathrm{CMI}_{\mathrm{gy}}$ was at or below the 50 -year average and punctuated by very dry conditions in 1994, the second most severe single-year drought over the record examined. This period corresponded with the most ex- 
tensive mountain pine beetle and western spruce budworm outbreaks to have occurred in the eastern Cascades since 1970 (Meigs et al., 2015). The inspection of aerial survey data collected annually since the 1940 s by federal and state agencies (available online: http://www.fs.usda.gov/detail/r6/ forest-grasslandhealth/) revealed that from 1985 to 1994 our grand fir sites showed signs of western spruce budworm defoliation for between 2 and 8 years, depending on the site. Western spruce budworm defoliation was also detected at three of our four ponderosa pine sites in 1986. Our woodland western juniper sites were not surveyed. We speculate that a multi-year drawdown of soil moisture due to insufficient recharge could have triggered the growth declines; which, in the case of grand fir and, to a lesser extent, ponderosa pine, were further exacerbated by insect attack. We suspect that grand fir growth is buffered against single-year meteorological droughts by ample soil water storage and recharge during wet years but is potentially vulnerable to soil water draw down due to sustained, multi-year periods of below average recharge. Soil moisture buffering might explain the lack of significant RWI-CMI correlations among grand fir. Although beyond the scope of this study, additional lines of evidence to support or refute this hypothesis could be drawn from treering isotopes, remote-sensing observations, and detailed hydraulic and ecological modeling. This presents an intriguing possibility that although annual growth tends to become decoupled from interannual fluctuations in water as conditions become wetter, forests occupying generally wet zones could experience greater impact from infrequent, multi-year periods of below-normal soil water recharge due to increased biotic pressure (e.g., insects) and morphological investment in competition for light over water.

Dendroecological analyses often involve sampling trees at multiple sites and then producing a mean ring-width chronology, at the site or regional level, that is used to reconstruct paleoclimatic conditions (e.g., Fritts, 2001) or assess spatial variability in historic forest growth (Berner et al., 2011; Bunn et al., 2013); however, growth and climate sensitivity of neighboring trees can vary widely (Berner et al., 2013; Bunn et al., 2005; Lloyd et al., 2010), and additional ecological information can be gained by examining growth-climate relations on an individualistic basis (Carrer, 2011). Our study demonstrates that not all trees within a site responded uniformly to drought, particularly at the ponderosa pine and grand fir sites. We did not explore the underlying mechanisms responsible for differences in drought response among individual trees within a site; however, factors such as age, genotype, competition, and microclimate could have contributed to these differences (Bunn et al., 2005, 2011; Hultine et al., 2013; Loranty et al., 2010) and warrant further investigation. The substantial intra- and interspecific variation in drought sensitivity that we observed highlights the need for fine spatial and taxonomical resolution when modeling potential climate change impacts on mixed-species forests in mountainous terrain.

\subsection{Constraints of long-term water availability on tree morphological traits}

As conditions became wetter, forest $\overline{\mathrm{WD}}$ declined, while $H_{\text {max }}$ and LA : SA increased, suggesting that trees responded to reduced hydraulic stress by increasing investment in competition for light to the extent that xylem water potentials were maintained within an operable range. These morphological changes, together with the observed differences in forest productivity and growth-climate relations across our network of sites, highlight trade-offs associated with investment in stress tolerance versus competitive ability (Grime, 2001; Reich, 2014). Since cavitation resistance (e.g., P50) tends to increase with WD (Chave et al., 2009; Hacke et al., 2001; Jacobsen et al., 2007), the decline in stem $\overline{\mathrm{WD}}$ that we observed between the juniper and fir communities is generally congruent with prior research showing that small western juniper branches are more resistant to drought-induced cavitation ( $\mathrm{P} 50=-9.0 \mathrm{MPa}$; Willson et al., 2008) than those of ponderosa pine (P50 $=-4.5$ to -4.8 ; Domec et al., 2009) or grand fir (P50 = -3.6 to $-6.1 \mathrm{MPa}$; Cochard, 2006; McCulloh et al., 2011) and, furthermore, that ponderosa pine stems are more cavitation-resistant $(\mathrm{P} 50=-2.5$ to -4.1 ; Domec et al., 2009) than those of grand fir (P50 $=-1.1$ to -1.0; McCulloh et al., 2011). Several previous syntheses similarly found general declines in WD (Swenson and Enquist, 2007; Wiemann and Williamson, 2002) and increases in P50 (Choat et al., 2012; Maherali et al., 2004) as conditions become wetter, yet these relationships tend to be quite weak since trees have evolved a variety of strategies to maintain hydraulic integrity, which depends on a suite of traits integrated at the organism level (e.g., stomatal regulation, xylem capacitance, embolism repair, LA : SA plasticity; Meinzer et al., 2010; Whitehead et al., 1984). High WD helps enable trees to endure hydraulic and mechanical stress, yet could come at a competitive cost in productive environments since dense wood is carbon-intensive to construct (Chave et al., 2009), generally has low hydraulic conductivity (Hacke et al., 2009; Reich, 2014), and limits the maximum height that a tree can obtain before buckling under its own weight (Swenson and Enquist, 2007).

Canopy height plays an important role in competition for light among plants (Hartmann, 2011; King, 1990) and, in trees, might ultimately be constrained by low leaf water potential inhibiting cell expansion and growth (Koch et al., 2004; Sala and Hoch, 2009) and/or photosynthesis (Koch et al., 2004; Ryan and Yoder, 1997) at the top of the canopy. In the juniper woodlands, low stem density (99-157 trees ha ${ }^{-1}$ ) and high water stress would place little premium on height growth, whereas ponderosa pine (127-334 trees ha ${ }^{-1}$ ) and grand fir (205-645 trees ha ${ }^{-1}$ ) formed progressively denser stands where greater canopy height would be more competitively beneficial and hydraulically feasible, which potentially explains the nearly 3 -fold increase in $H_{\max }$ that occurred among these forest communities. While taller trees can com- 
pete more effectively for light, the additional height causes them to experience lower xylem $\Psi$ (Whitehead et al., 1984) and could render these trees more vulnerable to drought impacts if conditions become increasingly arid (Hartmann, 2011; McDowell and Allen, 2015).

As with $H_{\max }$, forest LA : SA increased nearly 3-fold between the western juniper and grand fir stands, demonstrating that trees responded to increased water availability by increasing investment in light absorption relative to water transport. In a review of conifer LA : SA, Waring et al. (1982) reported that LA:SA varied from 0.14 to $0.75 \mathrm{~m}^{2} \mathrm{~cm}^{-2}$ across 14 conifer species and noted qualitatively that taxa with low LA: SA occurred in desiccating environments (e.g., J. occidentalis), whereas taxa with high LA: SA occupied mild climates (e.g., Abies lasiocarpa). Our results provide quantitative support for this earlier observation. Several studies have additionally shown that pine inhabiting sites with contrasting climatic conditions can adjust LA : SA to maintain xylem $\Psi$ within a narrow range that prevents cavitation (Maherali and DeLucia, 2001; Mencuccini and Grace, 1995). Low LA : SA enables trees to maintain higher leafspecific hydraulic conductance, which helps regulate leaf $\Psi$ (Maherali and DeLucia, 2001; Mencuccini and Grace, 1995), and is likely an important adaptation allowing western juniper to inhabit such arid sites. While low LA: SA helps ease leaf $\Psi$, this must be balanced against the increase in stem respiration resulting from greater investment in sapwood, given that stem respiration increases with both sapwood volume and temperature (Ryan et al., 1995). Relative to western juniper, the high LA:SA observed at the grand fir stands likely enables greater light absorption and photosynthate production, yet reduced water transport capabilities that could render these trees more susceptible to significant changes in water availability. Our findings demonstrate several adaptive responses to shifts in water availability, highlighting trade-offs between hydraulic stress tolerance and competition for light and suggesting potential changes in forest community morphological characteristics that could result from future changes in water availability due to sustained regional warming. Investigating the extent and causes of variation in traits across species and regions is a critical step towards understanding and modeling ecosystem properties and their responses to environmental change (Anderegg, 2015; Law, 2014; Westoby and Wright, 2006).

\subsection{Limitations}

We note several limitations associated with using an observational study to elicit the response of plant form and function to variation in climate, as well as with using CMI as an indicator of water availability. The observational approach makes it very challenging to separate the effect of a single environmental factor on plant form or function given that it is not possible to control the suite of environmental factors that can influence plant processes. For instance, although we focused on CMI as a dominant driver of carbon cycling and trait characteristics, there were additional differences among sites in climate (e.g., VPD, frost frequency, snow pack), soil, and disturbance history that independently, or interactively, could affect the processes of interest. Observational studies can elucidate existing spatial and temporal variation in plant response to climate or other controlling factors and are strengthened when coupled with experimental and modeling studies focused on the underlying mechanisms of response.

We used the CMI as an indicator of plant water availability and acknowledge that while useful, it is a rather simple index with several shortcomings. The index is easy to calculate from gridded climate data and serves as the water balance calculation underpinning the SPEI (Vicente-Serrano et al., 2010); together, they have been used to examine hydroclimatic controls over forest distribution (Hogg, 1997), productivity (Berner et al., 2013; Vicente-Serrano et al., 2013, 2014), and wildfire (Williams et al., 2014). The CMI is sensitive to changes in temperature and integrates both atmospheric inputs and withdrawals; however, it does not account for spatial variation in soil depth, soil water holding capacity, or snowpack that, along with rooting depth and architecture, further determine plant water availability. Additionally, we estimated CMI at each site using gridded PRISM climate data and an empirical equation for calculating $\mathrm{ET}_{0}$ from $T$, PPT, and $R$. Different climate data sets, or means of estimating $\mathrm{ET}_{0}$, could affect the statistical relationships that we observed, yet it is the overall tendencies, rather than the absolute statistical parameters, that we are most interested in capturing.

\subsection{Implications and future efforts}

Forests ecosystems in the Pacific Northwest are a critical element of the regional economy, culture, biodiversity and biophysics, yet future changes in water availability due to sustained regional warming could have significant adverse impacts on these unique and valuable ecosystems. Uncertainty in forest physiologic, demographic and disturbancerelated responses to changing environmental settings hinder projections of future forest conditions (Fisher et al., 2010; Hudiburg et al., 2013a; Law, 2014; van der Molen et al., 2011) and thus our adaptation and mitigation capabilities. For instance, $\mathrm{CO}_{2}$ fertilization might ameliorate some impacts of reduced water availability by increasing plant wateruse efficiency (WUE), yet the potential magnitude of this response is unclear. Ecological simulations suggest that warming and increased WUE could lead to a $\sim 20 \%$ increase in plant net primary productivity (NPP) by 2100 (Hudiburg et al., 2013b; Kang et al., 2014) or, conversely, that conifer forest NPP, carbon storage, and extent could decline substantially over this period due to reduced water availability and increased heat stress, despite increased WUE (Jiang et al., 2013). These divergent projections underscore the need to further reduce uncertainty in ecological models, which will 
necessitate investment in high-performance computing, experiments to elucidate physiologic mechanisms driving intraand interspecific differences in drought and heat sensitivity, regional field studies (such as ours) to provide physiological measurements for model parameterization, and a combination of remote-sensing and eddy covariance flux tower measurements to hone and validate model predictions. By understanding current climatic controls over forest ecosystem function and refining prognostic models of ecosystem processes, we can better anticipate the potential impacts of climate change and thus improve our mitigation and adaptation capabilities.

\section{Data availability}

In addition to providing species- and site-level summaries for each carbon cycling and trait variable, we include both the underlying data sets and code as a supplement so as to help enable future data syntheses, increase transparency, and prevent long-term data loss. The data sets include measurements of tree stem characteristics (e.g., DBH, height, bark thickness, wood density, sapwood area), tree-ring-width time series, leaf traits (e.g., carbon, nitrogen, specific leaf area, leaf longevity), and leaf area index. The leaf trait and sitelevel carbon cycling measurements were recently combined into a regional database with similar measurements made as part of other NASA-, DOE-, and EPA-funded projects at over 200 sites across the Pacific Northwest. The North American Carbon Program Terrestrial Ecosystem Research and Regional Analysis Pacific Northwest (NACP TERRAPNW) Forest Plant Traits, NPP, Biomass, and Soil Properties (1999-2014) data set (Law and Berner, 2016) is being publicly archived with the Oak Ridge National Laboratory Distributed Active Archive Center (ORNL DAAC). Furthermore, our tree-ring-width measurements will be made publicly available through the NOAA International Tree Ring Data Bank (NOAA ITRDB). In addition to archiving the data sets, we provide a set of $\mathrm{R}$ scripts that were written for data preprocessing, analysis, and visualization. We make these data sets and code freely available for noncommercial community use. Following the AmeriFlux Fair Use Policy (http://bwc.berkeley.edu/Amflux/fairuse.htm), we request to be (1) informed of how these data are used prior to publication and (2) either acknowledged via citation as the data source or, if the data set constitutes a significant contribution, offered participation as authors.

\section{The Supplement related to this article is available online at doi:10.5194/bg-12-6617-2015-supplement.}

Author contributions. L. T. Berner and B. E. Law designed the experiment. L. T. Berner performed data collection, processing, and analysis, and prepared the manuscript, with contributions form B. E. Law.

Acknowledgements. This work was supported by NASA Headquarters under the NASA Earth and Space Science Fellowship Program (Grant NNX14AN65H), the USDA National Institute of Food and Agriculture (Grant 2013-67003-20652), and the ARCS Foundation Scholar program. We thank Alex Westcott, Sam Lucero-Sickman, and Daniela Leite for field and/or laboratory assistance. We also thank Ben Bond-Lamberty, Adam Collins, and an anonymous reviewer for providing constructive feedback on earlier versions of the manuscript. We cite no conflicts of interest.

Edited by: P. Stoy

\section{References}

Allen, C.: Climate-induced forest dieback: an escalating global phenomenon?, Unasylva, 231, 42-49, 2009.

Allen, C. D., Macalady, A. K., Chenchouni, H., Bachelet, D., McDowell, N., Vennetier, M., Kitzberger, T., Rigling, A., Breshears, D. D., and Hogg, E. H.: A global overview of drought and heatinduced tree mortality reveals emerging climate change risks for forests, Forest Ecol. Manage., 259, 660-684, 2010.

Allen, R. G., Pereira, L. S., Raes, D., and Smith, M.: Crop evapotranspiration-Guidelines for computing crop water requirements, FAO Irrigation and drainage paper 56, FAO, Rome, 300 pp., 1998.

Anderegg, W. R.: Spatial and temporal variation in plant hydraulic traits and their relevance for climate change impacts on vegetation, New Phytol., 205, 1008-1014, 2015.

Anthoni, P. M., Law, B. E., and Unsworth, M. H.: Carbon and water vapor exchange of an open-canopied ponderosa pine ecosystem, Agr. Forest Meteorol., 95, 151-168, 1999.

Barclay, H. J.: Conversion of total leaf area to projected leaf area in lodgepole pine and Douglas-fir, Tree Physiol., 18, 185-193, 1998.

Barclay, H. J. and Goodman, D.: Conversion of total to projected leaf area index in conifers, Canadian J. Botany, 78, 447-454, 2000.

Berner, L. T., Beck, P. S. A., Bunn, A. G., Lloyd, A. H., and Goetz, S. J.: High-latitude tree growth and satellite vegetation indices: Correlations and trends in Russia and Canada (1982-2008), J. Geophys. Res., 116, G01015, doi:10.1029/2010jg001475, 2011.

Berner, L. T., Beck, P. S. A., Bunn, A. G., and Goetz, S. J.: Plant response to climate change along the forest-tundra ecotone in northeastern Siberia, Glob. Change Biol., 19, 3449-3462, 2013.

Bunn, A. G.: Statistical and visual crossdating in $\mathrm{R}$ using the dplR library, Dendrochronologia, 28, 251-258, 2010.

Bunn, A. G., Waggoner, L. A., and Graumlich, L. J.: Topographic mediation of growth in high elevation foxtail pine (Pinus balfouriana Grev. et Balf.) forests in the Sierra Nevada, USA, Global Ecol. Biogeogr., 14, 103-114, 2005.

Bunn, A. G., Hughes, M. K., and Salzer, M. W.: Topographically modified tree-ring chronologies as a potential means to improve paleoclimate inference, Climatic Change, 105, 627-634, 2011. 
Bunn, A. G., Hughes, M. K., Kirdyanov, A. V., Losleben, M., Shishov, V. V., Berner, L. T., Oltchev, A., and Vaganov, E. A.: Comparing forest measurements from tree rings and a spacebased index of vegetation activity in Siberia, Environ. Res. Lett., 8, 035034, doi:10.1088/1748-9326/8/3/035034, 2013.

Carrer, M.: Individualistic and time-varying tree-ring growth to climate sensitivity, PloS One, 6, e22813, doi:10.1890/02-0478, 2011.

Chave, J., Coomes, D., Jansen, S., Lewis, S. L., Swenson, N. G., and Zanne, A. E.: Towards a worldwide wood economics spectrum, Ecol. Lett., 12, 351-366, 2009.

Chen, J. M.: Optically-based methods for measuring seasonal variation of leaf area index in boreal conifer stands, Agr. Forest Meteorol., 80, 135-163, 1996.

Choat, B., Jansen, S., Brodribb, T. J., Cochard, H., Delzon, S., Bhaskar, R., Bucci, S. J., Feild, T. S., Gleason, S. M., Hacke, U. G., Jacobsen, A. L., Lens, F., Maherali, H., Martinez-Vilalta, J., Mayr, S., Mencuccini, M., Mitchell, P. J., Nardini, A., Pittermann, J., Pratt, R. B., Sperry, J. S., Westoby, M., Wright, I. J., and Zanne, A. E.: Global convergence in the vulnerability of forests to drought, Nature, 491, 752-755, 2012.

Cochard, H.: Cavitation in trees, C. R. Phys., 7, 1018-1026, 2006.

Collins, M., Knutti, R., Arblaster, J., Dufresne, J.-L., Fichefet, T., Friedlingstein, P., Gao, X., Gutowski, W. J., Johns, T., Krinner, G., Shongwe, M., Tebaldi, C., Weaver, A. J., and Wehner, M.: Long-term Climate Change: Projections, Commitments and Irreversibility. In: Climate Change 2013: The Physical Science Basis, Contribution of Working Group I to the Fifth Assessment Report of the Intergovernmental Panel on Climate Change, edited by: Stocker, T. F., Qin, D., Plattner, G.-K., Tignor, M., Allen, S. K., Boschung, J., Nauels, A., Xia, Y., Bex, V., and Midgley, P. M., Cambridge University Press, Cambridge, United Kingdom and New York, NY, USA, 2013.

Cook, E. R., Woodhouse, C. A., Eakin, C. M., Meko, D. M., and Stahle, D. W.: Long-term aridity changes in the western United States, Science, 306, 1015-1018, 2004.

Coops, N. C. and Waring, R. H.: Estimating the vulnerability of fifteen tree species under changing climate in Northwest North America, Ecol. Model., 222, 2119-2129, 2011.

Cregg, B.: Carbon allocation, gas exchange, and needle morphology of Pinus ponderosa genotypes known to differ in growth and survival under imposed drought, Tree Physiol., 14, 883-898, 1994.

Dai, A.: Increasing drought under global warming in observations and models, Nature Climate Change, 3, 52-58, 2013.

Daly, C., Halbleib, M., Smith, J. I., Gibson, W. P., Doggett, M. K., Taylor, G. H., Curtis, J., and Pasteris, P. P.: Physiographically sensitive mapping of climatological temperature and precipitation across the conterminous United States, Int. J. Climatol., 28, 2031-2064, 2008.

Dennison, P. E., Brewer, S. C., Arnold, J. D., and Moritz, M. A.: Large wildfire trends in the western United States, 1984-2011, Geophys. Res. Lett., 41, GL059576, doi:10.1002/2014GL059576, 2014.

Diffenbaugh, N. S. and Field, C. B.: Changes in ecologically critical terrestrial climate conditions, Science, 341, 486-492, 2013.

Domec, J.-C., Warren, J. M., Meinzer, F. C., and Lachenbruch, B.: Safety factors for xylem failure by implosion and air-seeding within roots, trunks and branches of young and old conifer trees,
International Association of Wood Anatomists, 30, 100-120, 2009.

Droogers, P. and Allen, R. G.: Estimating reference evapotranspiration under inaccurate data conditions, Irrigation and Drainage Systems, 16, 33-45, 2002.

Eidenshink, J., Schwind, B., Brewer, K., Zhu, Z., Quayle, B., and Howard, S.: A project for monitoring trends in burn severity, Fire Ecology, 3, 3-21, 2007.

Fisher, R., McDowell, N., Purves, D., Moorcroft, P., Sitch, S., Cox, P., Huntingford, C., Meir, P., and Ian Woodward, F.: Assessing uncertainties in a second-generation dynamic vegetation model caused by ecological scale limitations, New Phytol., 187, 666681, 2010.

Franklin, J. F. and Dyrness, C. T.: Natural vegetation of Oregon and Washington, Oregon State University Press, Corvallis, 1988.

Frazer, G. W., Trofymow, J., and Lertzman, K. P.: Canopy openness and leaf area in chronosequences of coastal temperate rainforests, Can. J. Forest Res., 30, 239-256, 2000.

Fritts, H. C.: Tree Rings and Climate, Blackburn Press, Caldwell, 567 pp., 2001.

Gholz, H. L.: Environmental Limits on Aboveground Net Primary Production, Leaf Area, and Biomass in Vegetation Zones of the Pacific Northwest, Ecology, 63, 469-481, 1982.

Gholz, H. L., Grier, C., Campbell, A., and Brown, A.: Equations for estimating biomass and leaf area of plants in the Pacific Northwest, Oregon State University, School of Forestry, Forest Research Lab, Corvallis, OR, 1979.

Grier, C. C. and Running, S. W.: Leaf area of mature northwestern coniferous forests: relation to site water balance, Ecology, 58 , 893-899, 1977.

Grime, J. P.: Vegetation classification by reference to strategies, Nature, 250, 26-31, 1974.

Grime, J. P.: Plant strategies, vegetation processes, and ecosystem properties, John Wiley \& Sons, New York, 2001.

Hacke, U., Jacobsen, A., and Pratt, R.: Xylem function of aridland shrubs from California, USA: an ecological and evolutionary analysis, Plant Cell Environ., 32, 1324-1333, 2009.

Hacke, U. G., Sperry, J. S., Pockman, W. T., Davis, S. D., and McCulloh, K. A.: Trends in wood density and structure are linked to prevention of xylem implosion by negative pressure, Oecologia, 126, 457-461, 2001.

Hargreaves, G. H. and Samani, Z. A.: Reference crop evapotranspiration from temperature, Appl. Eng. Agr., 1, 96-99, 1985.

Hartmann, H.: Will a 385 million year-struggle for light become a struggle for water and for carbon? - How trees may cope with more frequent climate change-type drought events, Glob. Change Biol., 17, 642-655, 2011.

Hicks, R. and Dugas, W.: Estimating ashe juniper leaf area from tree and stem characteristics, Journal of Range Management Archives, 51, 633-637, 1998.

Hogg, E. H.: Temporal scaling of moisture and the forest-grassland boundary in western Canada, Agr. Forest Meteorol., 84, 115$122,1997$.

Hogg, E. H. and Hurdle, P.: The aspen parkland in western Canada: A dry-climate analogue for the future boreal forest?, Water Air Soil Pollut., 82, 391-400, 1995.

Huang, K., Yi, C., Wu, D., Zhou, T., Zhao, X., Blanford, W. J., Wei, S., Wu, H., Ling, D., and Li, Z.: Tipping point of a conifer forest 
ecosystem under severe drought, Environ. Res. Lett., 10, 024011, doi:10.1088/1748-9326/10/2/024011, 2015.

Hudiburg, T., Law, B., Turner, D. P., Campbell, J., Donato, D., and Duane, M.: Carbon dynamics of Oregon and Northern California forests and potential land-based carbon storage, Ecol. Appl., 19, 163-180, 2009.

Hudiburg, T. W., Law, B. E., Wirth, C., and Luyssaert, S.: Regional carbon dioxide implications of forest bioenergy production, Nature Climate Change, 1, 419-423, 2011.

Hudiburg, T. W., Law, B. E., and Thornton, P. E.: Evaluation and improvement of the Community Land Model (CLM4) in Oregon forests, Biogeosciences, 10, 453-470, doi:10.5194/bg-10453-2013, 2013a.

Hudiburg, T. W., Luyssaert, S., Thornton, P. E., and Law, B. E.: Interactive Effects of Environmental Change and Management Strategies on Regional Forest Carbon Emissions, Environ. Sci. Technol., 47, 13132-13140, 2013b.

Hultine, K. R., Burtch, K. G., and Ehleringer, J. R.: Gender specific patterns of carbon uptake and water use in a dominant riparian tree species exposed to a warming climate, Glob. Change Biol., 19, 3390-3405, 2013.

Jacobsen, A. L., Pratt, R. B., Ewers, F. W., and Davis, S. D.: Cavitation resistance among 26 chaparral species of southern California, Ecol. Monogr., 77, 99-115, 2007.

Jiang, X., Rauscher, S. A., Ringler, T. D., Lawrence, D. M., Williams, A. P., Allen, C. D., Steiner, A. L., Cai, D. M., and McDowell, N. G.: Projected Future Changes in Vegetation in Western North America in the Twenty-First Century, J. Climate, 26, 3671-3687, 2013.

Kagan, J., Ohmann, J. L., Gregory, M. J., Tobalske, C., Hak, J., and Fried, J.: Final report on land cover mapping methods, map zones 8 and 9, Pacific Northwest ReGAP, Institute for Natural Resources, Oregon State University, Corvallis, OR, 2006.

Kang, S., Running, S. W., Kimball, J. S., Fagre, D. B., Michaelis, A., Peterson, D. L., Halofsky, J. E., and Hong, S.: Effects of spatial and temporal climatic variability on terrestrial carbon and water fluxes in the Pacific Northwest, USA, Environ. Modell. Softw., 51, 228-239, 2014.

Kern, J. S.: Geographic patterns of soil water-holding capacity in the contiguous United States, Soil Sci. Soc. Am. J., 59, 11261133, 1995.

King, D. A.: The adaptive significance of tree height, Am. Nat., 135, 809-828, 1990.

Knutson, K. C. and Pyke, D. A.: Western juniper and ponderosa pine ecotonal climate-growth relationships across landscape gradients in southern Oregon, Can. J. Forest Res., 38, 3021-3032, 2008.

Kobayashi, H., Ryu, Y., Baldocchi, D. D., Welles, J. M., and Norman, J. M.: On the correct estimation of gap fraction: How to remove scattered radiation in gap fraction measurements?, Agr. Forest Meteorol., 174-175, 170-183, 2013.

Koch, G. W., Sillett, S. C., Jennings, G. M., and Davis, S. D.: The limits to tree height, Nature, 428, 851-854, 2004.

Kozlowski, T. T., Kramer, P. J., and Pallardy, S. G.: The Physiological ecology of woody plants, Academic Press, San Diego, 1991.

Kruskal, W. H. and Wallis, W. A.: Use of ranks in one-criterion variance analysis, J. Am. Stat. Assoc., 47, 583-621, 1952.

Kunkel, K. E., Stevens, L. E., Stevens, S. E., Sun, L., Janssen, E., Wuebbles, D., Redmond, K. T., and Dobson, J. G.: Regional cli- mate trends and scenarios for the US National Climate Assessment: Part 5, Climate of the Southwest US, US Department of Commerce, National Oceanic and Atmospheric Administration, National Environmental Satellite, Data, and Information Service, Washington, D.C., 2013.

Landsberg, J. and Waring, R.: A generalised model of forest productivity using simplified concepts of radiation-use efficiency, carbon balance and partitioning, Forest Ecol. Manage., 95, 209228, 1997.

Law, B. E.: Regional analysis of drought and heat impacts on forests: current and future science directions, Glob. Change Biol., 20, 3595-3599, 2014.

Law, B. E. and Berner, L. T.: NACP TERRA-PNW: Forest Plant Traits, NPP, Biomass, and Soil Properties, 1999-2014, ORNL DAAC, Oak Ridge Tennessee, USA, 2016.

Law, B. E. and Waring, R. H.: Combining remote sensing and climatic data to estimate net primary production across Oregon, Ecol. Appl., 4, 717-728, 1994.

Law, B. E. and Waring, R. H.: Carbon implications of current and future effects of drought, fire and management on Pacific Northwest forests, Forest Ecol. Manage., 355, 4-14, 2015.

Law, B. E., Van Tuyl, S., Cescatti, A., and Baldocchi, D. D.: Estimation of leaf area index in open-canopy ponderosa pine forests at different successional stages and management regimes in Oregon, Agr. Forest Meteorol., 108, 1-14, 2001.

Law, B. E., Sun, O. J., Campbell, J., Van Tuyl, S., and Thornton, P. E.: Changes in carbon storage and fluxes in a chronosequence of ponderosa pine, Glob. Change Biol., 9, 510-524, 2003.

Law, B. E., Turner, D., Campbell, J., Sun, O. J., Van Tuyl, S., Ritts, W. D., and Cohen, W. B.: Disturbance and climate effects on carbon stocks and fluxes across Western Oregon USA, Glob. Change Biol., 10, 1429-1444, 2004.

Law, B. E., Arkebauer, T., Campbell, J. L., Chen, J., Sun, O., Schwartz, M., van Ingen, C., and Verma, S.: Terrestrial carbon observations: Protocols for vegetation sampling and data submission, Food and Agriculture Organization of United Nations, Rome, Italy, 2008.

Littell, J. S., Peterson, D. L., and Tjoelker, M.: Douglas-fir growth in mountain ecosystems: water limits tree growth from stand to region, Ecol. Monogr., 78, 349-368, 2008.

Lloyd, A. H., Bunn, A. G., and Berner, L.: A latitudinal gradient in tree growth response to climate warming in the Siberian taiga, Glob. Change Biol., 17, 1935-1945, 2010.

Loarie, S. R., Duffy, P. B., Hamilton, H., Asner, G. P., Field, C. B., and Ackerly, D. D.: The velocity of climate change, Nature, 462, 1052-1055, 2009.

Loranty, M. M., Mackay, D. S., Ewers, B. E., Traver, E., and Kruger, E. L.: Contribution of competition for light to withinspecies variability in stomatal conductance, Water Resour. Res., 46, W05516, doi:10.1029/2009WR008125, 2010.

Maherali, H. and DeLucia, E. H.: Influence of climate-driven shifts in biomass allocation on water transport and storage in ponderosa pine, Oecologia, 129, 481-491, 2001.

Maherali, H., Pockman, W. T., and Jackson, R. B.: Adaptive variation in the vulnerability of woody plants to xylem cavitation, Ecology, 85, 2184-2199, 2004.

Mathys, A., Coops, N. C., and Waring, R. H.: Soil water availability effects on the distribution of 20 tree species in western North America, Forest Ecol. Manage., 313, 144-152, 2014. 
McCulloh, K. A., Johnson, D. M., Meinzer, F. C., and Lachenbruch, B.: An annual pattern of native embolism in upper branches of four tall conifer species, Am. J. Bot., 98, 1007-1015, 2011.

McDowell, N. G.: Mechanisms linking drought, hydraulics, carbon metabolism, and vegetation mortality, Plant Physiol., 155, 10511059, 2011.

McDowell, N. G. and Allen, C. D.: Darcy's law predicts widespread forest mortality under climate warming, Nature Climate Change, 5, 669-672, 2015.

Means, J. E., Hansen, H. A., Koerper, G. J., Alaback, P. B., and Klopsch, M. W.: Software for computing plant biomassBIOPAK users guide, US Department of Agriculture, Forest Service, Pacific Northwest Research Station, Portland, OR, 184 pp., 1994.

Meigs, G. W., Kennedy, R. E., Gray, A. N., and Gregory, M. J.: Spatiotemporal dynamics of recent mountain pine beetle and western spruce budworm outbreaks across the Pacific Northwest Region, USA, Forest Ecol. Manage., 339, 71-86, 2015.

Meinzer, F. C., McCulloh, K. A., Lachenbruch, B., Woodruff, D. R., and Johnson, D. M.: The blind men and the elephant: the impact of context and scale in evaluating conflicts between plant hydraulic safety and efficiency, Oecologia, 164, 287-296, 2010.

Mencuccini, M. and Grace, J.: Climate influences the leaf area/sapwood area ratio in Scots pine, Tree Physiol., 15, 1-10, 1995.

Mote, P. A., Snover, K., Capalbo, S., Eigenbrode, S. D., Glick, P., Littell, J., Raymondi, R., and Reeder, S.: Northwest. In: Climate Change Impacts in the United States: The Third National Climate Assessment, edited by: Melillo, J. M., Richmond, T. C. C., and Yohe, G. W., US Global Change Research Program, Washington, DC, 2014.

Mote, P. W., Hamlet, A. F., Clark, M. P., and Lettenmaier, D. P.: Declining Mountain Snowpack in Western North America, B. Am. Meteorol. Soc., 86, 39-49, 2005.

Muller-Landau, H.: Interspecific and Inter-site Variation in Wood Specific Gravity of Tropical Trees, Biotropica, 36, 20-32, 2004.

Nippert, J. B. and Marshall, J. D.: Sources of variation in ecophysiological parameters in Douglas-fir and grand fir canopies, Tree Physiol., 23, 591-601, 2003.

Peng, C., Ma, Z., Lei, X., Zhu, Q., Chen, H., Wang, W., Liu, S., Li, W., Fang, X., and Zhou, X.: A drought-induced pervasive increase in tree mortality across Canada's boreal forests, Nature Climate Change, 1, 467-471, 2011.

Pérez-Harguindeguy, N., Díaz, S., Garnier, E., Lavorel, S., Poorter, H., Jaureguiberry, P., Bret-Harte, M., Cornwell, W., Craine, J., and Gurvich, D.: New handbook for standardised measurement of plant functional traits worldwide, Aust. J. Bot., 61, 167-234, 2013.

Peterman, W., Waring, R. H., Seager, T., and Pollock, W. L.: Soil properties affect pinyon pine-juniper response to drought, Ecohydrology, 6, 455-463, 2013.

Pilcher, J. R. (Ed.): Sample preparation, cross-dating, and measurement, Kluwer Academic, Boston, 1990.

Pockman, W. T., Sperry, J. S., and O'Leary, J. W.: Sustained and significant negative water pressure in xylem, Nature, 378, 715716, 1995.

R Core Team: R: A Language and Environment for Statistical Computing, R Foundation for Statistical Computing, Vienna, 2015.
Rehfeldt, G. E., Crookston, N. L., Warwell, M. V., and Evans, J. S.: Empirical Analyses of Plant-Climate Relationships for the Western United States, Int. J. Plant Sci., 167, 1123-1150, 2006.

Reich, P. B.: The world-wide "fast-slow" plant economics spectrum: a traits manifesto, J. Ecol., 102, 275-301, 2014.

Ruehr, N. K., Law, B. E., Quandt, D., and Williams, M.: Effects of heat and drought on carbon and water dynamics in a regenerating semi-arid pine forest: a combined experimental and modeling approach, Biogeosciences, 11, 4139-4156, doi:10.5194/bg11-4139-2014, 2014.

Runyon, J., Waring, R., Goward, S., and Welles, J.: Environmental limits on net primary production and light-use efficiency across the Oregon transect, Ecol. Appl., 4, 226-237, 1994.

Ryan, M. G. and Yoder, B. J.: Hydraulic Limits to Tree Height and Tree Growth, BioScience, 47, 235-242, 1997.

Ryan, M. G., Gower, S. T., Hubbard, R. M., Waring, R. H., Gholz, H. L., Cropper Jr., W. P., and Running, S. W.: Woody tissue maintenance respiration of four conifers in contrasting climates, Oecologia, 101, 133-140, 1995.

Sala, A. and Hoch, G.: Height-related growth declines in ponderosa pine are not due to carbon limitation, Plant Cell Environ., 32, 22-30, 2009.

Schwalm, C. R., Williams, C. A., Schaefer, K., Baldocchi, D., Black, T. A., Goldstein, A. H., Law, B. E., Oechel, W. C., and Scott, R. L.: Reduction in carbon uptake during turn of the century drought in western North America, Nat. Geosci., 5, 551556, 2012.

Schwarz, P., Law, B., Williams, M., Irvine, J., Kurpius, M., and Moore, D.: Climatic versus biotic constraints on carbon and water fluxes in seasonally drought-affected ponderosa pine ecosystems, Global Biogeochem. Cy., 18, GB4007, doi:10.1029/2004GB002234, 2004.

Sperry, J. S.: Hydraulics of vascular water transport, in: Mechanical integration of plant cells and plants, Springer, Berlin, 2011.

Sperry, J. S. and Tyree, M. T.: Mechanism of water stress-induced xylem embolism, Plant Physiol., 88, 581-587, 1988.

Swenson, N. G. and Enquist, B. J.: Ecological and evolutionary determinants of a key plant functional trait: wood density and its community-wide variation across latitude and elevation, Am. J. Bot., 94, 451-459, 2007.

Tezara, W., Mitchell, V., Driscoll, S., and Lawlor, D.: Water stress inhibits plant photosynthesis by decreasing coupling factor and ATP, Nature, 401, 914-917, 1999.

Tyree, M. T.: The cohesion-tension theory of sap ascent: current controversies, J. Exp. Bot., 48, 1753-1765, 1997.

USDA Natural Resources Conservation Service: Mountain snowpack as of April 1, 2015, Portland, Oregon, 2015.

van der Molen, M. K., Dolman, A. J., Ciais, P., Eglin, T., Gobron, N., Law, B. E., Meir, P., Peters, W., Phillips, O. L., Reichstein, M., Chen, T., Dekker, S. C., Doubková, M., Friedl, M. A., Jung, M., van den Hurk, B. J. J. M., de Jeu, R. A. M., Kruijt, B., Ohta, T., Rebel, K. T., Plummer, S., Seneviratne, S. I., Sitch, S., Teuling, A. J., van der Werf, G. R., and Wang, G.: Drought and ecosystem carbon cycling, Agr. Forest Meteorol., 151, 765-773, 2011.

van Mantgem, P. J., Stephenson, N. L., Byrne, J. C., Daniels, L. D., Franklin, J. F., Fulé, P. Z., Harmon, M. E., Larson, A. J., Smith, J. M., and Taylor, A. H.: Widespread increase of tree mortality rates in the western United States, Science, 323, 521-524, 2009. 
Van Tuyl, S., Law, B., Turner, D., and Gitelman, A.: Variability in net primary production and carbon storage in biomass across Oregon forests - an assessment integrating data from forest inventories, intensive sites, and remote sensing, Forest Ecol. Manage., 209, 273-291, 2005.

Vicente-Serrano, S. M., Beguería, S., and López-Moreno, J. I.: A multiscalar drought index sensitive to global warming: The standardized precipitation evapotranspiration index, J. Climate, 23, 1696-1718, 2010.

Vicente-Serrano, S. M., Gouveia, C., Camarero, J. J., Beguería, S., Trigo, R., López-Moreno, J. I., Azorín-Molina, C., Pasho, E., Lorenzo-Lacruz, J., Revuelto, J., Morán-Tejeda, E., and SanchezLorenzo, A.: Response of vegetation to drought time-scales across global land biomes, P. Natl. Acad. Sci., 110, 52-57, 2013.

Vicente-Serrano, S. M., Camarero, J. J., and Azorin-Molina, C.: Diverse responses of forest growth to drought time-scales in the Northern Hemisphere, Global Ecol. Biogeogr., 23, 1019-1030, 2014.

Walsh, J., Wuebbles, D., Hayhoe, K., Kossin, J., Kunkel, K., Stephens, G., Thorne, P., Vose, R., Wehner, M., Willis, J., Anderson, D., Doney, S., Feely, R., Hennon, P., Kharin, V., Knutson, T., Landerer, F., Lenton, T., Kennedy, J., and Somerville, R.: Our Changing Climate. In: Climate Change Impacts in the United States: The Third National Climate Assessment, edited by: Melillo, J. M., Richmond, T. C., and Yohe, G. W., US Global Change Research Program, 2014.

Waring, R.: Estimating forest growth and ef?ciency in relation to canopy leaf area, Adv. Ecol. Res., 13, 327-354, 1983.

Waring, R., Coops, N., Mathys, A., Hilker, T., and Latta, G.: Process-Based Modeling to Assess the Effects of Recent Climatic Variation on Site Productivity and Forest Function across Western North America, Forests, 5, 518-534, 2014.

Wenzel, L. C.: Volume Tables for Young-growth Conifers in the Northern Regions of California, University of California, Division of Agricultural Sciences, Berkeley, CA, 43 pp., 1977.

Westerling, A. L., Hidalgo, H. G., Cayan, D. R., and Swetnam, T. W.: Warming and earlier spring increase western US forest wildfire activity, Science, 313, 940-943, 2006.

Westoby, M. and Wright, I. J.: Land-plant ecology on the basis of functional traits, Trends Ecol. Evol., 21, 261-268, 2006.

Whitehead, D., Edwards, W. R. N., and Jarvis, P. G.: Conducting sapwood area, foliage area, and permeability in mature trees of Picea sitchensis and Pinus contorta, Can. J. Forest Res., 14, 940947, 1984
Wiemann, M. C. and Williamson, G. B.: Geographic variation in wood specific gravity: effects of latitude, temperature, and precipitation, Wood Fiber Sci., 34, 96-107, 2002.

Willamette National Forest: Upper North Santiam Watershed Analysis, USDA Forest Service, Pacific Northwest Region, Mill City, Oregon, 1995.

Williams, A. P., Allen, C. D., Macalady, A. K., Griffin, D., Woodhouse, C. A., Meko, D. M., Swetnam, T. W., Rauscher, S. A., Seager, R., and Grissino-Mayer, H. D.: Temperature as a potent driver of regional forest drought stress and tree mortality, Nature Climate Change, 3, 292-297, 2012.

Williams, A. P., Seager, R., Macalady, A. K., Berkelhammer, M., Crimmins, M. A., Swetnam, T. W., Trugman, A. T., Buenning, N., Noone, D., and McDowell, N. G.: Correlations between components of the water balance and burned area reveal new insights for predicting forest fire area in the southwest United States, Int. J. Wildland Fire, 4, 14-26, 2014.

Williamson, G. B. and Wiemann, M. C.: Measuring wood specific gravity... correctly, Am. J. Bot., 97, 519-524, 2010.

Willson, C. J., Manos, P. S., and Jackson, R. B.: Hydraulic traits are influenced by phylogenetic history in the drought-resistant, invasive genus Juniperus (Cupressaceae), Am. J. Bot., 95, 299314, 2008.

Wilmking, M. and Juday, G. P.: Longitudinal variation of radial growth at Alaska's northern treeline - recent changes and possible scenarios for the 21 st century, Global Planet. Change, 47, 282-300, 2005.

Woodhouse, C. A. and Overpeck, J. T.: 2000 years of drought variability in the central United States, B. Am. Meteorol. Soc., 79, 2693-2714, 1998.

Woodhouse, C. A., Meko, D. M., MacDonald, G. M., Stahle, D. W., and Cook, E. R.: A 1,200-year perspective of 21st century drought in southwestern North America, Proc. Natl. Acad. Sci., 107, 21283-21288, 2010.

Yamaguchi, D. K.: A simple method for cross-dating increment cores from living trees, Can. J. Forest Res., 21, 414-416, 1991.

Yang, R. C., Kozak, A., and Smith, J. H. G.: The potential of Weibull-type functions as flexible growth curves, Can. J. Forest Res., 8, 424-431, 1978. 